\title{
Life Histories, Salinity Zones, and Sublethal Contributions of Contaminants to Pelagic Fish Declines Illustrated with a Case Study of San Francisco Estuary, California, USA
}

\author{
Marjorie L. Brooks • Erica Fleishman • Larry R. Brown • Peggy W. Lehman • \\ Inge Werner • Nathaniel Scholz • Carys Mitchelmore • James R. Lovvorn • \\ Michael L. Johnson • Daniel Schlenk • Suzanne van Drunick • James I. Drever • \\ David M. Stoms • Alex E. Parker • Richard Dugdale
}

Received: 13 January 2011 /Revised: 15 June 2011 / Accepted: 25 October 2011 / Published online: 23 November 2011

(C) Coastal and Estuarine Research Federation 2011

\begin{abstract}
Human effects on estuaries are often associated with major decreases in abundance of aquatic species. However, remediation priorities are difficult to identify when declines result from multiple stressors with interacting sublethal effects. The San Francisco Estuary offers a useful case study of the potential role of contaminants in declines of organisms because the waters of its delta
\end{abstract}

M. L. Brooks $(\bowtie) \cdot$ J. R. Lovvorn

Department of Zoology, Southern Illinois University,

1125 E. Lincoln Dr., MC 6501,

Carbondale, IL 62901, USA

e-mail: mlbrooks@siu.edu

\section{E. Fleishman • D. M. Stoms}

Bren School of Environmental Science and Management, University of California,

3011 Bren Hall,

Santa Barbara, CA 93106, USA

L. R. Brown

U.S. Geological Survey, California Water Science Center, 6000 J Street,

Sacramento, CA 95819, USA

P. W. Lehman

California Department of Water Resources,

Division of Environmental Services,

3500 Industrial Boulevard,

West Sacramento, CA 95691, USA

I. Werner

Aquatic Toxicology Laboratory, Department of Anatomy, Physiology, and Cell Biology, School of Veterinary Medicine, University of California,

1330 F Haring Hall,

Davis, CA 95616, USA chronically violate legal water quality standards; however, direct effects of contaminants on fish species are rarely observed. Lack of direct lethality in the field has prevented consensus that contaminants may be one of the major drivers of coincident but unexplained declines of fishes with differing life histories and habitats (anadromous, brackish, and freshwater). Our review of available evidence

N. Scholz

NOAA Fisheries, Northwest Fisheries Science Center,

Environmental Conservation Division,

2725 Montlake Blvd. E.,

Seattle, WA 98112, USA

\section{Mitchelmore}

Chesapeake Biological Laboratory, University of Maryland Center for Environmental Science,

P.O. Box 38, Solomons, MD 20688, USA

M. L. Johnson

Center for Watershed Sciences, University of California,

One Shields Avenue,

Davis, CA 95616, USA

D. Schlenk

Department of Environmental Sciences, University of California, 2258 Geology,

Riverside, CA 92521, USA

S. van Drunick

Cooperative Institute for Research in Environmental Science (CIRES), University of Colorado at Boulder,

Box 216 UCB, Boulder, CO 80309, USA

\section{J. I. Drever}

Department of Geology and Geophysics, Department 3006,

University of Wyoming,

1000 University Avenue,

Laramie, WY 82071, USA 
indicates that examining the effects of contaminants and other stressors on specific life stages in different seasons and salinity zones of the estuary is critical to identifying how several interacting stressors could contribute to a general syndrome of declines. Moreover, warming water temperatures of the magnitude projected by climate models increase metabolic rates of ectotherms, and can hasten elimination of some contaminants. However, for other pollutants, concurrent increases in respiratory rate or food intake result in higher doses per unit time without changes in the contaminant concentrations in the water. Food limitation and energetic costs of osmoregulating under altered salinities further limit the amount of energy available to fish; this energy must be redirected from growth and reproduction toward pollutant avoidance, enzymatic detoxification, or elimination. Because all of these processes require energy, bioenergetics methods are promising for evaluating effects of sublethal contaminants in the presence of other stressors, and for informing remediation. Predictive models that evaluate the direct and indirect effects of contaminants will be possible when data become available on energetic costs of exposure to contaminants given simultaneous exposure to non-contaminant stressors.

Keywords Susceptibility to toxins - Bioenergetic costs . Impaired waterways $\cdot$ Multiple stressors $\cdot$ Pelagic organism decline $\cdot$ Climate change $\cdot$ Review

\section{Introduction}

Urbanization and agricultural development around estuaries are often associated with major changes in the abundance and composition of aquatic species (Nichols et al. 1986; Chaudry and Zwolsman 2008). Such shifts in estuarine communities coincide with altered hydrology, which affects

\footnotetext{
A. E. Parker $\cdot$ R. Dugdale

Romberg Tiburon Center for Environmental Studies, San

Francisco State University,

3152 Paradise Drive,

Tiburon, CA 94920, USA

Present Address:

E. Fleishman

John Muir Institute of the Environment, The Barn, University

of California,

One Shields Ave.,

Davis, CA 95616, USA

Present Address:

I. Werner

Swiss Centre for Applied Ecotoxicology,

Eawag/EPFL, Überlandstrasse 133,

8600, Dübendorf, Switzerland
}

salinity and turbidity, as well as inputs of municipal wastewater, fertilizers, and pesticides. A common challenge to prioritizing mitigation is that biota are responding to an array of stressors that each have sublethal effects. Contaminants may be important contributors to death by a thousand cuts, but the difficulty of quantifying their independent effects makes the often high economic cost of regulating individual stressors such as pesticides seem excessive and unfair when other factors such as wastewater output from municipalities also contribute. The resulting societal demand for unequivocal proof of appreciable mortality hinders progress toward remediation.

Even when waters are legally impaired according to a regulatory standard, it is often hard to attribute declines of a variety of species to contaminants on the basis of standard toxicological tests that use mortality of a few well-studied species as the main criterion of effect. The desire to generate legal criteria that address contaminants in isolation from confounding factors has led to reliance on standardized laboratory tests with limited environmental reality (Heugens et al. 2001). However, ecological effects of single or multiple contaminants, like the influences of weather, disease, food shortage, or behavioral disturbance, are more commonly sublethal contributors to a suite of adverse ecological conditions (Porter et al. 1984). Moreover, exposure to contaminants along with other stressors is often highly episodic, as after major storms or during blooms of toxic cyanobacteria. Such periodic events can greatly affect populations, but can go undetected by rigidly scheduled environmental monitoring of weekly or monthly habitat quality.

In fish, sublethal effects can occur as subtle or cryptic impairments such as altered behavior or suppressed immunity, which are difficult to measure even under controlled laboratory conditions. In rivers and streams or tidal systems, detecting such effects requires direct observation of fish impairment and immediate collection of biological and water samples before the toxicant moves away from the sampling location. A solution to the difficulty of measurement may lie in recognizing that energy is redirected from growth and reproduction toward avoiding, detoxifying, or eliminating pollutants, and that energy demands increase when contaminant exposure is coupled with other stressors such as limited food or altered salinity (Beyers et al. 1999a, b). Thus, measuring energetic costs by methods such as comparing growth rates or reproductive output to that of control organisms captures the impact of single and compounding stressors, and logistically, is more feasible than measuring cryptic effects of contaminants.

In estuaries, salinity and turbidity are key habitat parameters, and use of specific habitat zones varies among species and life stages depending on their osmoregulatory 
capability (Feyrer et al. 2010). In this paper, we present a conceptual model of the susceptibility to contaminants of four fish species with different habitat-use patterns (anadromous, brackish, and freshwater) in the San Francisco Estuary. In this scheme, we consider season, location, and mode of action of contaminants for each life stage. We then review published evidence of sublethal but statistically significant effects of contaminants (including inorganic nitrogen) on fish or their food in the San Francisco Estuary and elsewhere. We consider interactions among contaminants as well as with environmental factors (e.g., salinity, turbidity). We also explore how warming water temperatures associated with projected climate change may increase or decrease toxicity of contaminants depending on their mode of action. Finally, we highlight emerging research aimed at evaluating how sublethal stressors affect energy costs rather than mortality per se, and thereby address what may be the most practical measure of contaminant effects at the community level. Quantifying energy costs at the level of individuals may reveal energy deficits that lead to population declines; however, data collection and monitoring are generally not geared toward energy costs. Our goal is to recast thinking about contaminant effects and criteria for identifying them, and to encourage development of suitable methods of assessment.

\section{The Case Study of San Francisco Estuary}

Around the year 2002 in the San Francisco Estuary (California, USA), long-term declines in the abundance of multiple fish species accelerated abruptly, even though surrounding land use was stable and several years of aboveaverage precipitation were expected to improve the reproductive success of many of the fishes (Sommer et al. 2007; Thomson et al. 2010). The San Francisco Estuary (henceforth "the Estuary") consists of San Francisco Bay (most seaward region, including San Pablo Bay), Suisun Bay (intermediate, brackish waters), and the freshwater Sacramento-San Joaquin Delta (henceforth "the Delta") at the confluence of the Sacramento and San Joaquin rivers (Fig. 1). Declining species include native delta smelt (Hypomesus transpacificus), which is listed as endangered under the US and California endangered species acts, and longfin smelt (Spirinchus thaleichthys), which is listed as threatened under the California Endangered Species Act. Introduced threadfin shad (Dorosoma petenense) and young of the year (age- 0 ) striped bass (Morone saxatilis) have also declined (Fig. 2).

The Delta is designated as an impaired waterway under Section 303(d) of the US Clean Water Act, meaning that the allowable total maxima of daily loads of some contaminants are chronically or repeatedly exceeded. To evaluate biological effects of water quality, researchers have collected waters from various locations across the entire Delta. After exposing organisms to those water samples under controlled laboratory conditions, researchers documented widespread toxicity to invertebrates, planktonic algae, and larval fish during times when the four fish species of interest are in the Delta (Fig. 1). The percentages of toxic samples range from $0 \%$ to $15 \%$ depending on test species, sampling frequency, and location, which is highly heterogeneous among projects (Werner et al. 2000; Johnson et al. 2010; Werner et al. 2010). Despite such evidence of the presence of toxic chemicals in Delta waters, fish kills clearly associated with contaminants have not been documented since the 1980s. The criterion of overt mortality among wild populations as evidence of effect may overlook the contribution of chronic contaminant exposure to declines caused by sublethal impairment and the cumulative effects of multiple stressors.

\section{Life Histories of Declining Fishes}

Delta smelt are endemic to the brackish and freshwaters of the Delta (Moyle 2002; Bennett 2005) (Fig. 3). The species has a 1-year life cycle. Spawning occurs in the spring in the freshwater portions of the Delta, although the exact characteristics of spawning habitat have not been identified. Larvae and juveniles move downstream into the lowsalinity zone of the Delta and Suisun Bay (Moyle et al. 1992; Dege and Brown 2004), where they remain through the summer and autumn as juveniles and pre-spawning adults (Feyrer et al. 2007; Nobriga and Feyrer 2008). They feed on zooplankton, mainly calanoid copepods (Moyle 2002). Longfin smelt generally spawn at the end of their second year, although some spawn in their third year (Moyle 2002; Rosenfield and Baxter 2007). Like delta smelt, longfin smelt spawn in freshwater, but in the late winter or early spring. Larvae and juvenile longfin smelt migrate downstream to low-salinity waters. Juveniles continue moving seaward, and most of the population matures in San Francisco Bay and the near-coastal ocean.

Striped bass is a long-lived species that was introduced to the Estuary in 1871 (Dill and Cordone 1997). The population grew rapidly and supported a commercial fishery (Moyle 2002). Despite declines in abundance, striped bass still support a recreational fishery. Striped bass typically first spawn at 5 years of age. Most spawning occurs in the lower Sacramento River in the spring. The semi-buoyant eggs and larvae move with the current into low-salinity reaches of the Delta (Dege and Brown 2004). Salinity and turbidity largely define the habitat of age- 0 striped bass, which is confined mainly to the tidal portion of the Sacramento River upstream of its confluence with the San Joaquin River. Older striped bass occupy habitats 
Fig. 1 Locations within the San Francisco watershed of the legally defined Delta (delineated by bold black line), municipal wastewater facilities, maximum extent of cyanobacteria (M. aeruginosa) blooms, and locations of intermittent, acute toxicity of field-collected surface waters to larval fish (fathead minnows, P. promelas), invertebrates (water fleas, $C$. dubia), or freshwater algae (Selenastrum capricornutum) in laboratory tests, based on standard US Environmental Protection Agency protocols, from 2008 to 2009

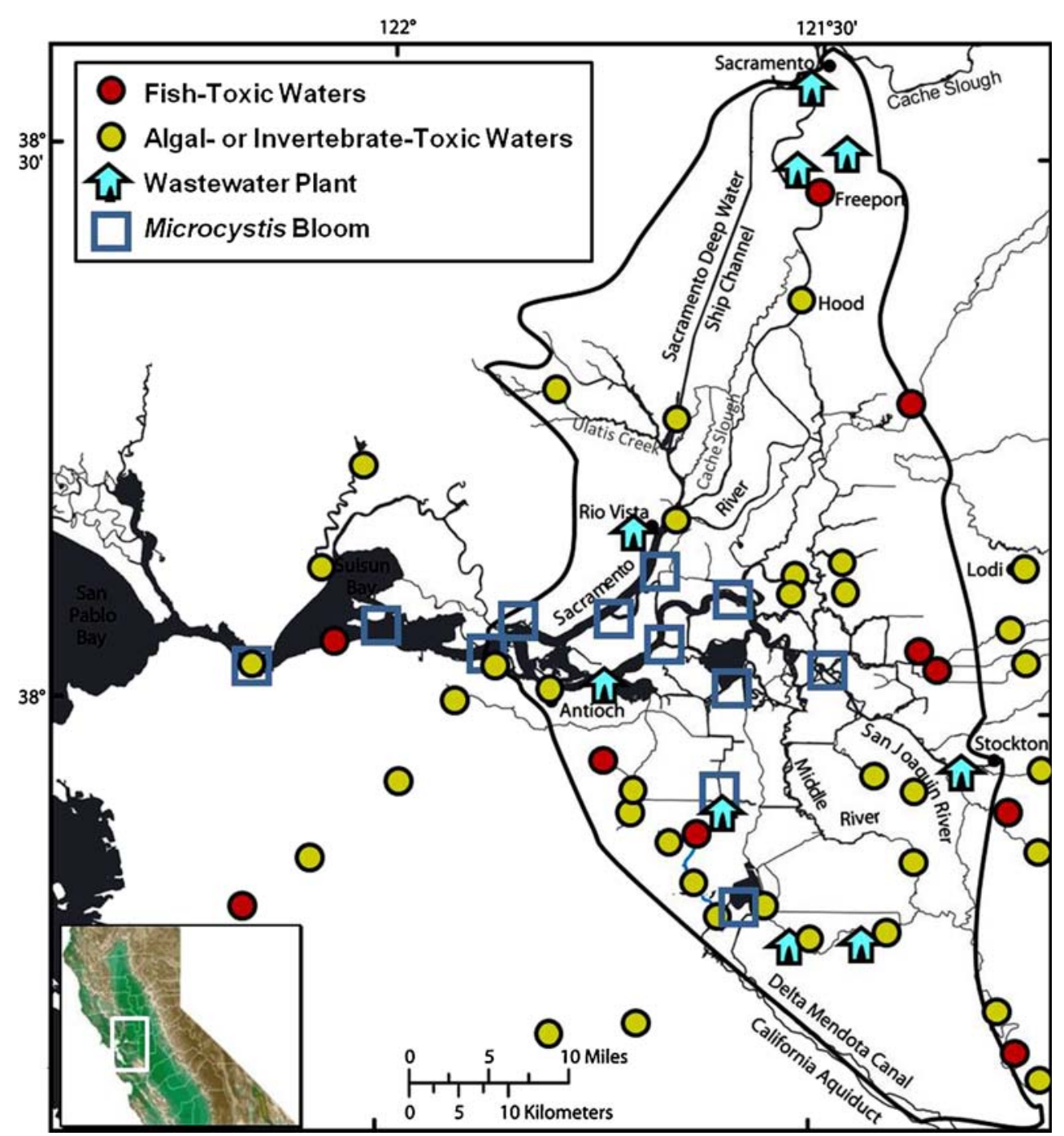

throughout the rivers, estuary, and near-coastal ocean. Threadfin shad is a freshwater obligate that was introduced into Central Valley reservoirs as forage for largemouth bass (Micropterus salmoides), an introduced sport fish, and rapidly colonized downstream areas including the Delta (Dill and Cordone 1997). Threadfin shad are omnivores that can filter feed or sight feed on individual particles. They generally spawn at 2 years of age but may spawn at 1 or 3 years in the freshwater portions of the Delta during the late spring and summer (Moyle 2002). Juveniles and adults occur in the same freshwater areas.

In general, habitat for these fishes is defined on the basis of environmental conditions rather than specific geographic locations. In wet years, for example, brackish water tends to move seaward. In dry years, brackish water is more landward. Because the location of the transition between brackish and freshwater varies as a function of precipitation and Delta outflow, the extent of habitat can expand or contract depending on whether the transition is located within the Delta, where channels tend to be narrow and deep, or in Suisun Bay, which is wide and relatively shallow. Striped bass and threadfin shad are sensitive to low levels of dissolved oxygen (Moyle 2002), which can occur during summer and autumn in the extreme upstream limits of the south Delta (Lehman 2004) and in the some sloughs in Suisun Marsh when they receive water from autumn drainage of reclaimed marshlands (Feyrer et al. 2007). However, in the Delta as a whole, low dissolved oxygen is uncommon.

Overlap of all four species is limited (see Fig. 3). All occur in the freshwater portions of the estuary in spring, and all but threadfin shad occur in the brackish water portion of the estuary in spring. Rather than maturing to adulthood in the low-salinity zone of the Estuary like delta smelt and striped bass, juvenile longfin smelt migrate farther downstream to San Francisco Bay. Thus, the spatial distribution of juveniles and adults varies among species. Delta smelt occur in the Delta and Suisun Bay, longfin smelt occur in San Francisco Bay and the ocean, threadfin shad are confined to the freshwater portions of 


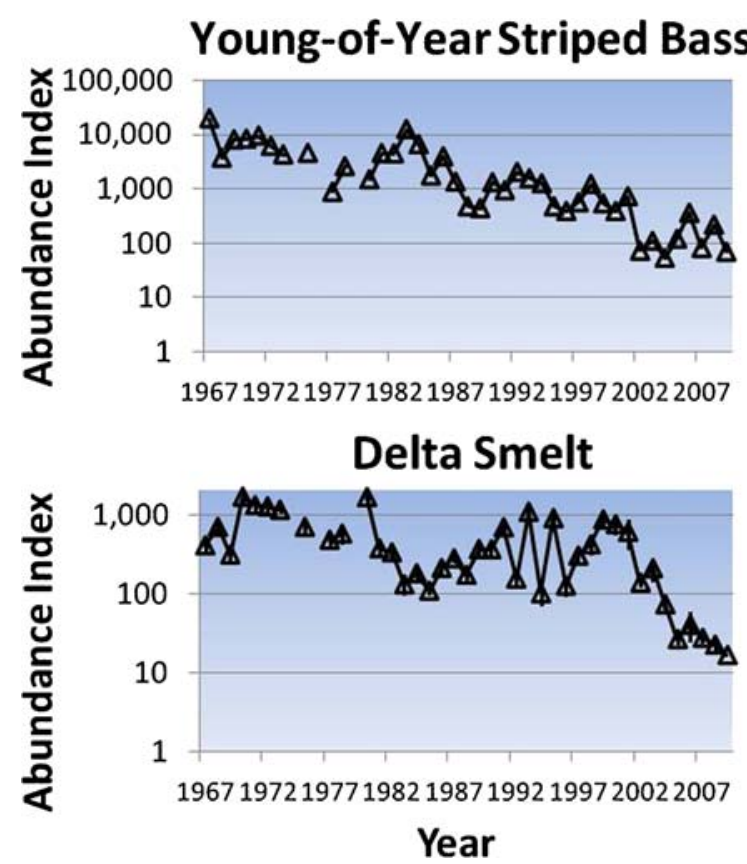

Fig. 2 Abundance indices of pelagic fishes in the Delta from 1967 to 2009. The indices are based on numbers of fish captured during midwater trawls from September to December, but do not represent

the delta, and adult striped bass are found throughout the Estuary.

Conceptual Model of Interactions Between Life Stages and Stressors

Fish and their foods may respond differently to sublethal exposures to contaminants depending on life stage and how exposures occur. For example, the responses to pulsed pesticide inputs after storms (Guo et al. 2007) can differ from the responses to chronic exposure to municipal wastewater throughout the year (Dugdale et al. 2007). Whether pulsed or chronic, contaminant exposure can cause organisms to divert energy from growth, reproduction, and predator avoidance to mitigate sublethal contaminant effects (Beyers et al. 1999b; Goto and Wallace 2010). Vertebrates regulate sublethal effects physiologically by processes such as sequestration (e.g., deposition of mercuric selenide as insoluble particles in the liver) (Yang et al. 2008), incorporation of organic contaminants into fat reserves (Greenfield et al. 2008; Ostrach et al. 2008), enzymatic detoxification (Wallace et al. 2003), and excretion (Linton et al. 1998a). Organisms can also acclimate to chronic contaminant exposure via compensatory processes. For example, many fish, including striped bass, can detoxify metals through greater production of the metalbinding protein metallothionein (Geist et al. 2007; Spearow et al. 2011). Because contaminants are agents of natural selection, over multiple generations some organisms devel-

\section{Threadfin Shad}
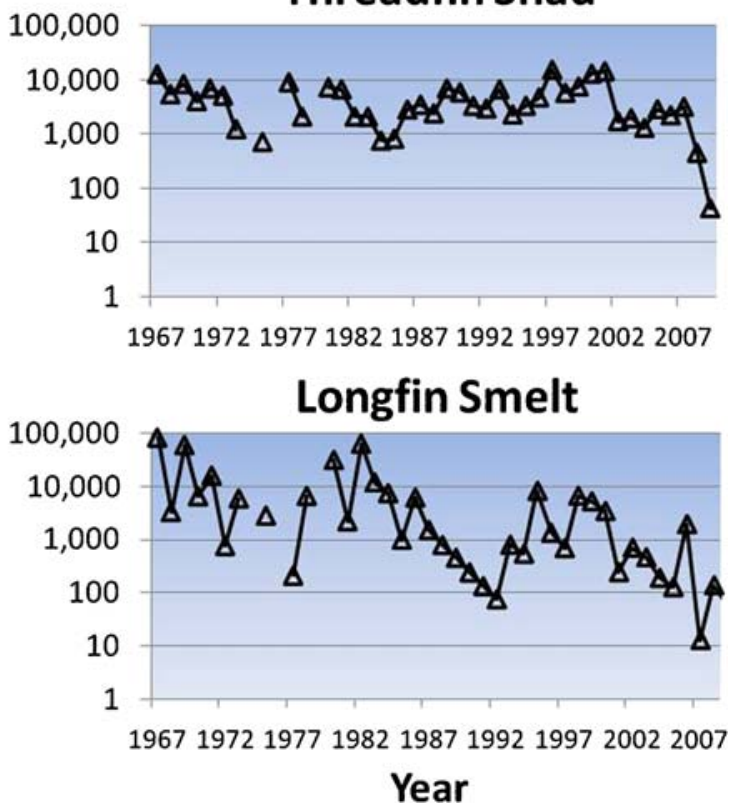

actual abundances. Note differences in scale of $y$-axes. (Data source: California Department of Fish and Game, http://www.delta.dfg.ca.gov/ data/mwt/charts.asp)

op heritable resistance to aromatic contaminants such as polychlorinated biphenols (PCBs; electronic coolants), polycyclic aromatic hydrocarbons (PAHs; by-products of combustion) (Wirgin and Waldman 2004; Yuan et al. 2006; Wirgin et al. 2011), pesticides (Relyea and Hoverman 2006), and metals (Meyer et al. 2003; Guinand et al. 2010). Compensatory processes are not particularly efficient in developing fish. Depending on the species and the contaminant, less than $10 \%$ of the dose lethal to an adult can be fatal to a juvenile (Boening 2000). Thus, larvae and juveniles are the most sensitive life stages of pelagic fishes.

From late winter through early summer, just before and during spawning, several factors may increase the vulnerability of delta smelt, longfin smelt, age- 0 striped bass, and threadfin shad to toxic exposure (Fig. 3). During this period, the life histories, habitat, and geographic location of the four fish species coincide when they migrate to the freshwater portions of the Delta to spawn (Fig. 2). Moreover, spawning and the life stages that are most responsive to contaminants overlap with periods of high rainfall. Winter and spring storms can increase nitrogen and contaminant loading to concentrations that can be acutely toxic (Fig. 3, effect A) (Beighley et al. 2008; Kuivila and Hladik 2008). Storm runoff can double or triple mercury loads (Domagalski et al. 2004) and increase concentrations of pesticides as much as 10-fold (Brady et al. 2006; Guo et al. 2007).

Contaminants can kill fish prey, effectively mimicking resource limitation as can occur from the introduction of a 


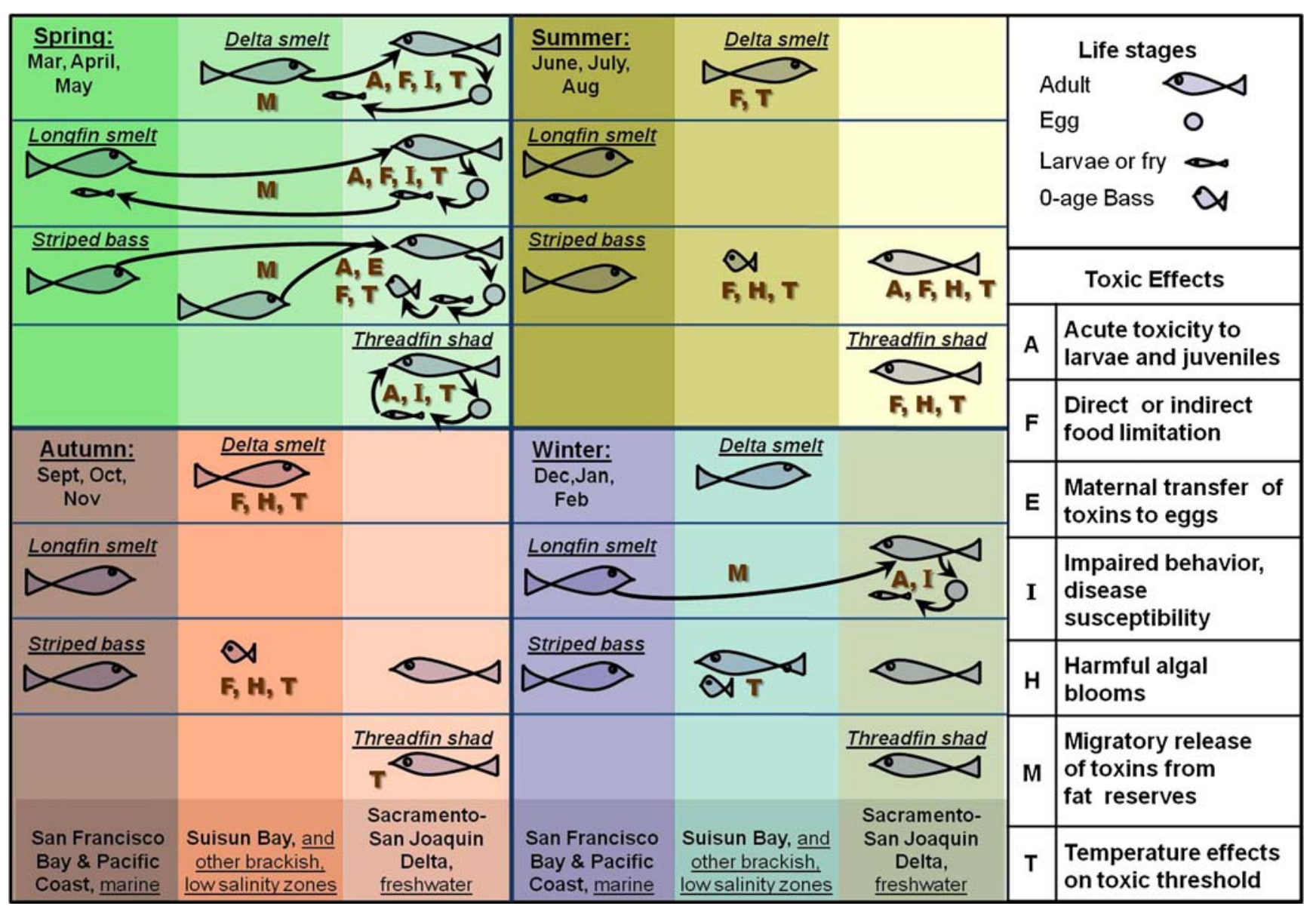

Fig. 3 Conceptual model of how phenology and toxic mechanisms potentially affect four pelagic fishes in the San Francisco Estuary at specific life stages. Turbidity and conductivity increase from east (Sacramento-San Joaquin Delta) to west (San Francisco Bay). All life stages are affected by hydrologic changes in turbidity and salinity, impaired water quality from stochastic rainfall events, and wastewater inputs that impair habitat quality

limitation (Bennett et al. 1995). Fish growth depends on adequate caloric intake but food quality is also important. $\mathrm{Ng}$ et al. (2009) demonstrated that environmentally realistic concentrations of calcium in their foods protected rainbow trout (Oncorhynchus mykiss) against both respiratory (branchial) and dietary uptake of cadmium.

During egg production, female fish transfer contaminants to eggs, which can impair development and survival of embryos (Fig. 3, effect E). For species with short life cycles, and thus, limited time to accumulate toxins, adverse effects from maternal transfer to eggs are less likely. Such species include delta smelt, which spawn at age 1 and then die, and threadfin shad and longfin smelt, which spawn at age 2 or 3 and then die. However, striped bass begin spawning at age 5 and survive to spawn multiple times (Moyle 2002); allowing more time to accumulate persistent chemicals in their tissues that can be passed to their eggs. Chemicals found in bass eggs include polychlorinated biphenyls, polybrominated diphenylethers (flame retardants), and current-use and banned pesticides (Ostrach et al. 2008). 
During migration to spawning grounds in the Delta, anadromous fish mobilize energy reserves, which releases organic contaminants from adipose tissues (Debruyn et al. 2004) (Fig. 3, effect M). Among the four pelagic fish considered here, increased exposure from release of toxins from fat reserves is probably greatest for the anadromous striped bass and longfin smelt, which travel to the Delta from San Francisco Bay and the coastal ocean (Moyle 2002). Release of contaminants from fat is probably least for threadfin shad, which are confined to the freshwater portions of the Delta and upstream watersheds (Dill and Cordone 1997).

The survival and health of fishes can be strongly affected by pollutants that alter behavior and immune function (Eder et al. 2007) (Fig. 3, effect I). Sublethal exposure of larvae to contaminants can impair swimming performance and increase vulnerability to predators (Floyd et al. 2008). Common environmental concentrations of copper, organophosphates, and pyrethroids have been shown to impair salmonid olfaction (Sandahl et al. 2007). Sense of smell is important for these migratory animals to find food and locate their natal stream. Olfactory damage of juveniles leaving their natal stream prevents them from imprinting properly, making it impossible for them to return to the correct stream for spawning (Sandahl et al. 2007). Regarding immunological effects, statistically significant alterations in gene expression of factors involved in neurological immune function occurred in delta smelt after their 24-h exposure to a low concentration $\left(0.0625 \mu \mathrm{g} \mathrm{L}^{-1}\right)$ of the pyrethroid pesticide, esfenvalerate (Connon et al. 2009).

Pelagic fishes have different life histories and use different regions of the Delta and Estuary during different seasons; as a result, contaminant exposure also tends to vary among locations and seasons. For example, central California's climate is conducive to extensive blooms of Microcystis aeruginosa, a toxic cyanobacterium that became abundant around 1999 in the warm, freshwaters of the central and southern Delta (Fig. 3, effect H). Depending on flow and temperature, blooms can extend westward into the low-salinity zone (Fig. 1). Of the four pelagic fishes, only longfin smelt likely do not encounter the blooms because their population mostly occurs downstream of Suisun Bay during the summer bloom period (Fig. 3).

Some environmental conditions can increase the susceptibility of organisms to contaminants (Fig. 3, all seasons). Salmonids exposed to brackish salinities increase their output and activity of the enzymes (flavin containing monooxygenases) that convert fenthion, an organophosphate biocide, into more toxic forms. Thus, salinity increases the toxicity of fenthion (Lavado et al. 2009a). Salinity also requires energy for osmoregulation. Osmoregulatory stress can alter metabolic rate and increase susceptibility of fish to copper (Pistole et al. 2008). Costs of resistance to one contaminant can increase susceptibility to another stressor or decrease fecundity. For example, killifish (Fundulus heteroclitus) survived exposure to sediment contaminants from the Elizabeth River in Virginia (USA), but the fish died when subjected to the same contaminant concentrations combined with the additional stressors of photoenhanced toxicity and hypoxia (Meyer and Di Giuliuo 2003). Fish adapted to elevated cadmium exhibit reduced fecundity, reduced offspring size, and longer maturation time, suggesting energetic trade-offs in resource allocation (Xie and Klerks 2004).

Turbidity and temperature can alter susceptibility of fishes to contaminants. Increased turbidity can limit penetration of ultraviolet radiation, which protects organisms from photoactivation of PAHs (Ireland et al. 1996). However, greater turbidity can decrease the energy intake of visual predators by hampering their feeding success. Decreased turbidity can also limit the food intake of larval fish by increasing their perceived threat from predators, causing them to hide rather than forage (Domenici et al. 2007). Regarding temperature (Fig. 3, effect T), when juvenile and adult rainbow trout were exposed to temperatures approaching their thermal maximum, sublethal concentrations of ammonia significantly impaired protein metabolism and diminished growth in starved fish but also in fish fed ad libitum (Linton et al. 1998b; Morgan et al. 2001).

\section{Contaminant Stressors}

The Delta receives many natural and anthropogenic compounds from agricultural and urban areas. Although agricultural applications of pesticides are well documented, transport mechanisms for most pesticides from fields to waterways are not well understood and concentrations of most pesticides are not monitored (Kuivila and Hladik 2008). Urban applications are not well documented, nor is transport well characterized. Thus, the transport, fate, and ultimate loads of all chemicals entering the Delta cannot be rigorously quantified and there are no long-term monitoring programs that document concentrations (Johnson et al. 2010). Accordingly, we used available data from the Estuary to qualitatively evaluate the biological importance to fish of four categories of major contaminants - metals, nutrients, toxic algae, and pesticides. These contaminants are common to populated estuaries worldwide (Matthiessen and Law 2002; Ducrotoy et al. 2000; Luo et al. 2004; Bollmohr et al. 2007; Couillard et al. 2008). We also briefly review other contaminants that may have been chronic contributors to the long-term decrease in fish abundance but probably did not cause the recent declines.

Metals and the Metalloid Selenium

There is no evidence that acute toxicity of selenium, mercury, or copper contributed to recent declines of pelagic 
fishes in the Estuary, but chronic effects may have played a role in the long-term declines. The metalloid selenium is one of the most difficult elements to regulate because it is an essential trace nutrient that becomes a potent toxicant if consumed in excess of nutritional requirements. Fish uptake of selenium varies as a function of diet with greatest uptake and toxic effects on benthic feeding top predators (Stewart et al. 2004). Selenium exposure during development causes diagnostic skeletal deformities that affect swimming performance (Chapman et al. 2010). At this time, it appears that neither irrigation of seleniferous soils in the San Joaquin River drainage nor selenium from industrial sources along Suisun Bay (Doblin et al. 2006) affect pelagic fishes; although it was a concern in the past (Luoma and Presser 2009).

Mercury in the Estuary is derived from geothermal features and from mining in the Delta watershed during the mid 1800s (Domagalski et al. 2004). Urban runoff and wastewater also contribute mercury, copper, silver, and other metals (Flegal et al. 2005). Concentrations of inorganic mercury in the Delta range from undetectable to $2 \mu \mathrm{g} \mathrm{L} \mathrm{L}^{-1}$ (Johnson et al. 2010). Sublethal mercury concentrations between 1 and $50 \mu \mathrm{g} \mathrm{L}^{-1}$ can reduce fertility, slow growth, and impair neurologic and endocrine functions of fish (Boening 2000).

Selenium and mercury accumulation are positively correlated in the tissues of many organisms. Observations of coinciding and ostensibly lethal concentrations of mercury and selenium in wild marine organisms led to the hypothesis that selenium protected organisms against mercury toxicity (Koeman et al. 1973; Dietz et al. 2000). The protective effect of selenium against mercury has been supported by laboratory studies of model vertebrates and cell cultures (Yang et al. 2008). Nonetheless, protection varies depending on the form of both selenium (selenite, selenate, selenocysteine, and selenomethionine) and mercury (total mercury, inorganic mercury, and methylmercury), routes of administration for each (dietary or respiratory), and whether organisms are dosed with selenium before, during, or after mercury exposure (Yang et al. 2008). An example of the complexity of dose and uptake comes from seleniferous lakes in Canada where concentrations of selenium and mercury in the tissues of young walleye (Stizosedion vitreum) are negatively correlated even though mercury exposure from upwind smelting operations is high. These findings suggest that chronic exposure to high selenium concentrations may prevent mercury uptake (Yang et al. 2010). It appears that eventual formation of inert, inorganic mercuric selenide depends on initial formation of selenoproteins (selenomethionine and selenocysteine) as well as the availability of the antioxidant enzyme glutathione, which mediates the process (Yang et al. 2008, 2011). In fish that are native to the Estuary, the protective effect of selenium against methylmercury toxicity was demonstrated in laboratory studies on larval Sacramento splittail (Pogonichthys macrolepidotus) that were fed selenomethionine before being fed a dose of mercury (Deng et al. 2008). Laboratory findings have not been replicated in the field or laboratory for other species. Fishes in the Estuary contain mercury and selenium but tissue concentrations of these elements were not reported as ratios within the same individual, and thus cannot be related to possible protection against mercury toxicity (Saiki et al. 1992; Greenfield et al. 2005).

Before remediation, Iron Mountain Mine in the Sacramento River watershed discharged substantial amounts of metals including copper, with toxic effects on anadromous salmonids returning to natal streams; however, the mine has met remediation criteria since 2003 (USEPA 2008). Current copper loadings from agricultural and urban runoff reflect the common use of copper sulfate as an algaecide. Purchases of copper sulfate in Delta counties totaled 1.4 to 1.8 million $\mathrm{kg} /$ year between 1996 and 2004 (CDPR 2009). Copper is highly toxic to invertebrates and larval fish, damaging DNA and impairing immune function and behavior. Copper concentrations as high as 4,032 $\mathrm{g} \mathrm{L}^{-1}$ were reported between 2004 and 2007 (Johnson et al. 2010), although surface water concentrations in the Delta typically average $2 \mu \mathrm{g} \mathrm{Cu} \mathrm{L}^{-1}$ (P. Lehman, unpublished data). The latter concentration can halve the swimming performance of salmon in freshwater (Sandahl et al. 2007). Juvenile delta smelt are relatively sensitive to copper, with a median lethal concentration of $17.8 \mu \mathrm{g} \mathrm{L}^{-1}$ after a 7-day exposure. Moreover, patterns of gene expression indicated likely impairment of swimming performance, digestion, and immune function (Werner et al. 2009; Connon et al. 2011). Complexation of copper with inorganic anions (mainly carbonates) and natural organic carbon reduces the available fraction of copper (Brooks et al. 2007a, b). Estimates of the biologically available fraction indicate that copper is not acutely toxic to fish at the environmental concentrations found in San Francisco Bay (Buck et al. 2007). However, neither acute nor sublethal effects of mercury or copper have been directly tested in waters from the Bay.

Aluminum is not a major toxicant in the alkaline waters of the Estuary ( $\mathrm{pH}$ range 7.2 to 8.0) (USGS 2011). Aluminum toxicity occurs in acidified waters in parts of Puget Sound (Washington, USA) (Landis et al. 2004), the southern regions of the Canadian Shield, and the northeastern United States, including the upper tributaries of Chesapeake Bay (Maryland and Virginia) where granitic soils have little buffering capacity (Hall et al. 1993). In acidified waters below $\mathrm{pH}$ 6.0, aluminum occurs as monomeric species $\left(\mathrm{Al}^{3+}, \mathrm{AlOH}^{2+}, \mathrm{Al}(\mathrm{OH})_{2}{ }^{+}, \mathrm{Al}\right.$ $(\mathrm{OH})_{3}{ }^{\circ}$, and $\left.\mathrm{Al}(\mathrm{OH})_{4}{ }^{-}\right)$that deposit on gill surfaces and smother the animal. However, when $\mathrm{pH}$ remains above 
6.0, monomeric aluminum binds with carbonates and the toxic forms of aluminum are absent (Gensemer and Playle 1999). Moreover, aluminum is not toxic when bound into particles by iron, natural organic matter (Roy and Campbell 1997), or silica. However, under acidic conditions found in the upper reaches of some estuaries, aluminum is highly toxic to larval striped bass and salmonids (Hall et al. 1993; Nilsen et al. 2010). Even after anadromous salmon migrate to waters with a neutral $\mathrm{pH}$, transient exposure to aluminum in mildly acidic water significantly decreases survival and growth (Kroglund et al. 2007).

\section{Inorganic Nitrogen}

Of the three forms of nitrogen commonly used in fertilizersammonia $\left(\mathrm{NH}_{3}\right)$, ammonium $\left(\mathrm{NH}_{4}{ }^{+}\right)$, and nitrate $\left(\mathrm{NO}_{3}{ }^{-}\right)_{-}$ only $\mathrm{NH}_{3}$ is acutely toxic to fish. Agricultural inputs of commercial fertilizer to Delta waterways did not increase after 2000, but the human population within $30 \mathrm{~km}$ of the Delta grew by about $11 \%(350,000)$ between 2000 and 2007 . Nitrogenous input into waterways from wastewater treatment plants increases by $\sim 1$ metric ton/day per 100,000 people (Jassby 2008). Primary treatment (solids removal) and secondary treatment (microbial consumption of organics) of water is sometimes followed by advanced-secondary treatment that removes $\mathrm{NH}_{3}$ and $\mathrm{NH}_{4}{ }^{+}$but not $\mathrm{NO}_{3}{ }^{-}$. Except for the city of Stockton, which initiated advanced-secondary water treatment in 2004, major cities in the Delta region, such as Sacramento, do not conduct this final water treatment (Table 1). Whether from fertilizers or wastewater plants,

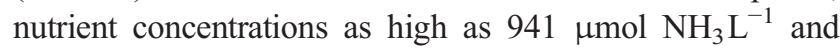
$7,800 \mu \mathrm{mol} \mathrm{NO}_{3}{ }^{-} \mathrm{L}^{-1}$ (Johnson et al. 2010) have made some Delta waters unsuitable for human use and aquatic organisms (Gowdy and Grober 2003). (Criteria for drinking water are $1,800 \mu \mathrm{mol} \mathrm{NH} \mathrm{L}^{-1}$ and $161 \mu \mathrm{mol} \mathrm{NO}{ }_{3}{ }^{-} \mathrm{L}^{-1}$; criteria for freshwater organisms are 176 to $300 \mu \mathrm{mol} \mathrm{NH} \mathrm{L}_{3}^{-1}$ depending on $\mathrm{pH}$, temperature, and life stage).

High nutrient loadings can have complex repercussions in waterways. For example, $\mathrm{NH}_{4}^{+}$may indirectly limit availability of food for pelagic fish (Fig. 3, effect F). Although $\mathrm{NH}_{4}{ }^{+}$is a plant nutrient, some primary producers use $\mathrm{NO}_{3}^{-}$more efficiently. Moreover, elevated $\mathrm{NH}_{4}{ }^{+}$ $\left(>4 \mu \mathrm{mol} \mathrm{L}{ }^{-1}\right.$ ) inhibits $\mathrm{NO}_{3}^{-}$uptake by phytoplankton, including diatoms. Lower diatom production directly reduces abundances of large-diameter algal cells that fall within the optimum size range for adult copepod food and are positively correlated with zooplankton biomass in the
Table 1 Wastewater effluent outputs in cities in the Sacramento and San Joaquin valleys (California, USA) as of 2006
Secondary treatment removes organic molecules, and advanced-secondary treatment removes $\mathrm{NH}_{3}, \mathrm{NH}_{4}{ }^{+}$, and $\mathrm{NO}_{3}{ }^{-}$. Data source: http://www.water. ca.gov/publications/browse. $\mathrm{cfm}$ ?display=topic\&$\mathrm{pub}=120,382,10872$

\begin{tabular}{|c|c|c|c|}
\hline \multirow[t]{2}{*}{ Location } & \multicolumn{2}{|c|}{ Final step in wastewater treatment } & \multirow{2}{*}{ 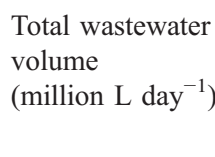 } \\
\hline & $\begin{array}{l}\text { Secondary } \\
\left(\text { million } \mathrm{L}_{\text {day }}{ }^{-1}\right)\end{array}$ & $\begin{array}{l}\text { Advanced-2nd } \\
\left(\text { million L day }{ }^{-1}\right)\end{array}$ & \\
\hline $\begin{array}{l}\text { Delta } \\
\text { Sacramento, Stockton, Vacaville } \\
\text { Tracy, Manteca/Lathrop } \\
\text { West Sacramento, Brentwood } \\
\text { Discovery Bay, Mountain House }\end{array}$ & 692.5 & 142.4 & 834.9 \\
\hline $\begin{array}{l}\text { Sacramento Basin } \\
\text { Roseville-Dry Creek, Chico } \\
\text { Redding-Clear Grove, Davis } \\
\text { Roseville-Pleasant Grove } \\
\text { Yuba City, Oroville, Woodland } \\
\text { Redding-Stillwater, Lincoln, Placerville, } \\
\text { Grass Valley, Olivehurst, Placer County } \\
\text { University of California Davis } \\
\text { Red Bluff, Anderson, Linda } \\
\text { Auburn, Willows, Corning }\end{array}$ & 100.2 & 183.3 & 283.5 \\
\hline $\begin{array}{l}\text { San Joaquin Basin } \\
\text { Modesto, Turlock, Merced } \\
\text { Lodi, Deer Creek, Galt } \\
\text { El Dorado Irrigation District } \\
\text { El Dorado Hills }\end{array}$ & 175.0 & 40.0 & 215.0 \\
\hline Total discharge & 967.7 & 365.6 & $1,333.3$ \\
\hline Percent of total & 72.6 & 27.4 & 100 \\
\hline
\end{tabular}


Delta (Lehman et al. 2004; Dugdale et al. 2007). Currently, high $\mathrm{NH}_{4}^{+}$concentrations in Suisun Bay prevent diatom blooms in spring (Dugdale et al. 2007). Diatom blooms are believed to provide optimal food for production of zooplankton during a critical period in the nutrition and growth of several pelagic fishes, including delta smelt.

Throughout the Delta, sublethal concentrations of $\mathrm{NH}_{4}{ }^{+}$ and $\mathrm{NH}_{3}$ were negatively correlated with 10-day growth of the amphipod Hyalella azteca. However, concentrations that cause effects in Hyalella are far higher than those found in the water samples. Historical data from the Delta suggest that increasing $\mathrm{NH}_{4}{ }^{+}$loads since 1982 might be associated with output from sewage treatment plants (Jassby 2008). Possibly toxicity was due to a mixture of ammonia with other contaminants or other contaminants in which ammonia happened to co-occur (Werner et al. 2010), suggesting that ammonia could act as an indicator of water quality.

Nutrients can affect oxygen availability to ectotherms during summer and autumn when flows are minimal and warmer waters diminish the pool of available oxygen, which intensifies any hypoxia caused by nocturnal respiration of algal blooms. Although high ammonium levels associated with the Stockton wastewater treatment facility once triggered high oxygen demand mainly from nitrification (Gowdy and Grober 2003; Lehman et al. 2004), new facilities with advanced-secondary treatment (Table 1) have eliminated this problem. Currently, low dissolved oxygen rarely occurs in the Delta due to low light and high vertical mixing. Hypoxia might occur in some smaller sloughs with poor circulation but, to our knowledge, it has been documented only for Suisun Marsh. In general, the waters of the Delta where pelagic fish live are not hypoxic.

\section{Cyanobacterial Blooms}

Although blooms of cyanobacteria such as $M$. aeruginosa are not usually classified as contaminants, they can be directly toxic to fish (Fig. 3, effect A) or reduce the quality or quantity of food (Fig. 3, effect F). In the Delta, blooms of $M$. aeruginosa have recurred each summer since 1999 (Lehman et al. 2008) (Fig. 1) except for summer 2010, which had high flow and unseasonably cool water temperatures in August and September (Lehman, unpublished data). M. aeruginosa produces several forms of the toxin microcystin, which promote liver cancer in humans and fish (Ibelings and Chorus 2007; Ibelings and Havens 2008). Juvenile striped bass collected from areas where $M$. aeruginosa was abundant in the Delta contained microcystins and expressed liver biomarkers consistent with carcinogen exposure (Fig. 3, effect H) (Lehman et al. 2010). Long-term exposure to diets containing microcystins reduces survival of embryos and inhibits the growth, impairs liver function, and decreases the RNA/DNA ratio of juveniles and adults in Medaka (Oryzias latipes) (Malbrouck and Kestemont 2006; Deng et al. 2010). Blooms are most likely to affect threadfin shad and age-0 striped bass, species that remain in the freshwater portions of the Delta in summer, but high flows move these toxic cyanobacteria into brackish portions of the estuary where other fish, including delta smelt, may be affected (Lehman et al. 2005). Tidal mixing may also move cyanobacteria into upstream freshwater tidal habitats.

$M$. aeruginosa may also produce cascading effects on the food web (Fig. 3, effect F). Allelopathy (biochemicals that influence the growth, survival, and reproduction of other organisms) associated with cyanobacterial blooms can affect the base of the food web by altering phytoplankton community composition (Suikkanen et al. 2005). $M$. aeruginosa can also outcompete other primary producers at high temperature, light, and nutrient concentration (Schindler 1977; Munkes 2005). Fewer diatoms and green algae and more cryptophytes occurred where $M$. aeruginosa was abundant in the Delta (Lehman et al. 2010). Whereas laboratory and field results suggest that zooplankton can achieve positive growth on cyanobacteria, cyanobacteria are generally less nutritious than phytoplankton as food for zooplankton and can lead to shifts in the species composition (Wilson et al. 2006; Tillmanns et al. 2008). M. aeruginosa blooms in the Delta were associated with a decrease in the cladocera to calanoid copepod ratio (Lehman et al. 2010). Because diatoms and green algae have the optimum feeding diameter for copepods in the Delta, their loss can also limit the availability of phytoplankton food with high carbon content, particularly in the low salinity zone where pelagic fish are abundant (Lehman 2000). The co-occurrence of other cyanobacteria with $M$. aeruginosa may further decrease the quality of zooplankton food during blooms.

Whether M. aeruginosa or its toxin, microcystin, directly affect zooplankton in the Delta is less clear. Calanoid copepods can selectively avoid feeding on $M$. aeruginosa and copepod abundance was not lower within blooms (Lehman et al. 2010). However, microcystins are present in zooplankton tissue and the adverse affect of this toxin on health and survival of the critical zooplankton prey species in the Delta, the copepods Pseudodiaptomus forbesi and Eurytemora affinis, in laboratory tests suggests populations may not reach maximal abundance (Ger et al. 2009; Lehman et al. 2010).

Pesticides in Current Use

Agricultural, commercial, and urban purchases of pesticides within the Delta and the upstream watershed averaged 21 million kg annually from 1990 to 2007, the period of record 
(CDPR 2009). Urban applications are not monitored. Agencies test concentrations in waterways of about half of 161 pesticides applied in annual amounts greater than $500 \mathrm{~kg}$ by agricultural and commercial users. Those that are monitored are detected in runoff, mainly from December through July (Kuivila and Hladik 2008), which is the period of fish spawning and larval development (Fig. 3, effect A). Organophosphates such as diazinon and chlorpyrifos have repeatedly exceeded water quality standards, and contributed to listing of the Delta as an impaired waterway. Carbamate pesticides (carbaryl, carbofuran) and organophosphates from agricultural and urban drainages explained $23 \%$ to $63 \%$ of the variation in recruitment of larval striped bass in 1989-1991 (Bailey et al. 1994). In 1994 and 1995, organophosphate and carbamate insecticides in water samples collected throughout the Delta intermittently caused acute toxicity to Ceriodaphnia dubia, an invertebrate surrogate for Delta prey species (Werner et al. 2000). Concerns about the toxicity of organophosphates to humans resulted in reduced use (primarily of diazinon) by $40 \%$ to $79 \%$ as of 2000 (Dileanis et al. 2002; Kratzer et al. 2002). Nonetheless, the most commonly applied insecticide in 2006 was chlorpyrifos $(198,495 \mathrm{~kg}$ ) (Kuivila and Hladik 2008), an organophosphate that is toxic to zooplankton and fish (Eder et al. 2007). Pyrethroid pesticides, the favored replacement for organophosphates, are highly toxic to fishes and a million times more toxic than organophosphates to invertebrates (e.g., E. affinis), causing paralysis and eventual death (Werner and Moran 2008). The trend toward greater pyrethroid use has coincided with abrupt declines in abundances of pelagic fishes.

The source of pyrethroids appears to be largely urban. Seventy-five percent of the 198,295 kg of pyrethroids used in 2006 (Kuivila and Hladik 2008) were applied in urban areas (Spurlock and Lee 2008). During 2008 and 2009, Weston and Lydy (2010) investigated the toxicity of pyrethroids by exposing $H$. azteca to water samples from point sources (three wastewater treatment plants) and nonpoint sources (six urban and eight agricultural locations). About one third of samples from agricultural runoff contained pyrethroids, and $10 \%$ of samples contained toxic concentrations. In contrast, nearly all samples of non-point urban runoff from Sacramento, Stockton, and Vacaville were toxic. Those samples contained pyrethroid concentrations of 8 to $20 \mathrm{ng} \mathrm{L}{ }^{-1}$, which are four to ten times the concentration that causes paralysis in $H$. azteca (Weston and Lydy 2010).

In municipal wastewaters, advanced-secondary treatment appears to mitigate the toxicity of pyrethroids. The city and county of Sacramento are served by the County of Sacramento Regional Wastewater Treatment Plant, which does not conduct advanced-secondary treatment. This plant discharged pyrethroids at concentrations higher than at any other location, and every sample tested was toxic to $H$. azteca (Weston and Lydy 2010). One third of samples collected in outflow from the Vacaville plant were toxic. At the Stockton plant, which conducts advanced-secondary treatment, pyrethroids were infrequently detected and toxicity was never observed. Regardless of source, at 16 mainstem sites across the Delta, pyrethroids in conjunction with ammonia and potentially organophosphates impaired growth, or survival of $H$. azteca in about $10 \%$ of 701 water samples collected between January 2006 and December 2007 (Werner et al. 2010).

\section{Other Contaminants}

Several categories of contaminants may be having longterm effects on the condition of fish in the Delta. Applications of several pesticides have not increased or have ceased in recent years. Consequently, they are unlikely to drive recent declines in abundance of fishes, although as chronic stressors they may have contributed to longer-term declines. We discuss them given relatively high concern, yet limited knowledge, about their potential effects. Organochlorine insecticides, mainly dichlorodiphenyltrichloroethane (DDT; banned in 1972 in the United States) and DDT breakdown products, are potent neurotoxins. Because these persistent chemicals bind strongly to sediments they probably have minimal effect on pelagic fishes, except during sediment resuspension by dredging operations or if fish consume benthic organisms. Nonetheless, DDT and breakdown products can accumulate in long-lived species such as striped bass (Ostrach et al. 2008).

Urban and industrial sources are the main contributors of PCBs and PAHs. The PCBs, banned since 1976, suppress immune response in aquatic biota and humans (Ostrach et al. 2008; Ankley et al. 2009). Most adult fish can enzymatically neutralize PAHs, but these carcinogens are highly toxic to early life stages. Nearly all sediments sampled in the Delta contained PCBs (88\%) and PAHs (98\%) in 2006. Many sediment samples (68\%) exceeded $2.5 \mu \mathrm{g} \mathrm{PCB} \mathrm{kg}{ }^{-1}$ organic carbon, which is equivalent to 2.5 times the US Environmental Protection Agency's criterion for freshwater organisms (SFEI 2007).

Many compounds, from flame retardants and plasticizers to pharmaceuticals and personal care products, remain in municipal wastewater after treatment (Ankley et al. 2009), particularly during the summer when rainfall is virtually nil in the Sacramento-San Joaquin Valley (Loraine and Pettigrove 2006). Long-lived fish such as striped bass can transfer PCBs, polybrominated diphenyl ethers (PBDEs, flame retardants), and chlorinated pesticides to their eggs (Fig. 3, effect E), producing larvae with abnormal brain and liver development and impaired growth compared to 
hatchery-reared striped bass (Ostrach et al. 2008). Concentrations of flame retardants are high in clams (Corbicula fluminea) from the Sacramento and San Joaquin rivers. Concentrations of PBDE in tissues of striped bass increased 4-fold, from $\sim 400$ to $\sim 2,000 \mathrm{pg} \mathrm{g}^{-1}$ lipid, between 1997 and 2003 (Hoenicke et al. 2007). Many of these compounds, which mimic natural endocrine hormones, can affect reproduction of wild fish (Kidd et al. 2007; Lavado et al. 2009b). However, few endocrine disruptors are monitored in the Estuary (Hoenicke et al. 2007). When monitored in agricultural drainages, natural estrogens from human wastewater and synthetic estrogens from oral contraceptives were seldom above detection limits (Lavado et al. 2009b).

Unexpected interactions can stem from pharmaceutical inputs. For example, Robinson et al. (2005) exposed five aquatic organisms (a cyanobacterium, M. aeruginosa; duckweed, Lemna minor; a green alga, Pseudokircheriella subcapitata; a crustacean, Daphnia magna; and a fish, Pimephales promelas) in the laboratory to fluoraquinolone antibiotics at concentrations that occur in the field. Of the organisms tested, M. aeruginosa was most sensitive to the antibiotic (Robinson et al. 2005). Because $70 \%$ to $90 \%$ of antibiotics are excreted unchanged (Lopes de Souza et al. 2009; Kim et al. 2011), wastewater from hospital and veterinary use might inhibit bacterial growth that could have either positive or negative effects on fishes. Input can be high (Lopes de Souza et al. 2009), but a fate and transport study showed that $90 \%$ of the antibiotics chlortetracycline, sulfamethazine, and tyolsin were removed by abiotic processes such as adsorption to soil particles (Kim et al. 2011). To our knowledge, antibiotics are not present in Delta waters, although wastewater effluents in the Delta contain insecticides, herbicides, plasticizers, perfume and lotion stabilizers, hypertension medication, and analgesics (Loraine and Pettigrove 2006).

\section{Potential Effects of Climate Change}

Climate models project increased frequency of severe storms, extended drought, and $2^{\circ} \mathrm{C}$ to $6^{\circ} \mathrm{C}$ increases in air temperatures in California by 2100 (Cayan et al. 2006). Aside from potential effects on salinity and turbidity that greatly influence the habitat quality of fishes (Feyrer et al. 2010), such patterns could increase the frequency of pollutant pulses from overland runoff during storms, increase the frequency and severity of droughts that might concentrate contaminants through evaporation, and raise water temperatures that increase metabolic rates of ectotherms and alter their susceptibility to contaminants. For example, storms can increase mercury and diazinon concentrations at sites within the San Francisco watershed 10to 100 -fold, exceeding water quality criteria (Domagalski et al. 2004; Guo et al. 2007). Reduced summer flows (i.e., less dilution) and evaporation may increase instream contaminant concentrations. However, drought may also decrease the flushing of solutes into waterways.

Without any change in water chemistry, warming water temperatures can convert sublethal concentrations to biologically lethal levels or vice versa. In ectotherms, warming water temperatures can increase contaminant dose because their respiration and feeding rates must increase to support higher metabolic rates. However, the response to higher dose varies depending on whether enzymatic breakdown or elimination can keep pace with uptake and whether contaminants are converted physiologically to more toxic forms. The effect of higher metabolic rate on biologic response also depends on the mode of action of the contaminant (e.g., respiratory failure versus internal bleeding), and whether the relationship between temperature and toxicity is linear or exponential (Harwood et al. 2009).

For example, most pyrethroids (Weston et al. 2009) and DDT have greater toxicity at lower temperatures. Some pyrethroids are exponentially more toxic at lower temperatures because enzymatic breakdown slows. Toxicity of pyrethroids appears unchanged at temperatures above about $23^{\circ} \mathrm{C}$ (Weston et al. 2009), probably because the efficiency of enzymatic processes does not improve above a thermal optimum. Physical effects of DDT, also a neurotoxin, increase at lower temperatures because nerve sensitivity increases (Harwood et al. 2009). Conversely, raising water temperature by $1^{\circ} \mathrm{C}$ to $2{ }^{\circ} \mathrm{C}$ caused 1.5 - to 100 -fold increases in the toxicity of metals, carbamates, organophosphates (including chlorpyrifos), and some organochlorines other than DDT (Lydy et al. 1990; Boening 2000; Heugens et al. 2001; Harwood et al. 2009). Large increases in susceptibility to toxins can occur when metabolic rates elevated by warmer temperatures increase uptake of pollutants. The higher dose apparently overwhelms excretion and enzymatic depuration. For compounds that are physiologically converted to more toxic forms (e.g., chlorpyrifos) the higher rate of metabolic transformation also increases their toxicity (Harwood et al. 2009).

Warming water temperatures can indirectly and directly reduce or tax the energy reserves that fish require to mitigate pollutants. Warmer water indirectly reduces caloric intake because fish become lethargic and decrease their foraging activity, which lowers consumption. Because warmer waters carry less oxygen (e.g., oxygen saturation in freshwater decreases by $\sim 8 \%$ as temperature increases from $20^{\circ} \mathrm{C}$ to $25^{\circ} \mathrm{C}$ ), higher water temperatures can trigger the first mechanism of thermal intolerance-failure to meet oxygen demand because oxygen supply is inadequate. For example, some fish 
species require cool night temperatures to offset thermal stress during the day (Caissie 2006; Portner and Knust 2007), indicating that diminished nocturnal oxygen constitutes a hypoxic environment for fish. Fish make several physiologic adjustments to tolerate hypoxia, initially increasing their basal metabolic rate, which directly depletes their energy reserves. Eventually, their survival depends on a shift to time-limited anaerobic metabolism that causes the buildup of organic acids (e.g., succinate) and reactive oxygen species in tissues, increasing the demand for antioxidants (Portner and Knust 2007). Food limitation may speed the pace and severity of this process because energy reserves are inadequate for diverting blood supply to critical functions and for meeting greater antioxidant demand (Dupont-Prinet et al. 2009).

While hypoxia is not currently a general concern in the Estuary, models indicate that future water temperatures in the Delta will exceed the thermal tolerance of delta smelt for much of the year (Wagner et al. 2011). Effects of climate change will vary among species depending on trade-offs between decreased toxicity of some pesticides and greater susceptibility to other contaminants, the timing and magnitude of chemical uses, hydrologic control of exposure spikes, and predator-prey interactions. Ultimately, higher minimum daily water temperatures (Fig. 4) could be a predictor of the toxic susceptibility of contaminant mixtures and energetic costs on pelagic fishes.
Emerging Research Approaches

In future research, use of energy as a common currency may increase the ability to evaluate contaminant interactions with oxygen demand, growth, reproduction, and ultimately survival of wild populations. For example, molecular biomarkers such as thyroid hormone levels or gene expression (Baker et al. 2009; Brar et al. 2010), when coupled with histological assays of body condition, can reveal the energetic consequences of suppressed thyroid function and tumor growth in wild-caught organisms. Field studies are important in determining how energetic responses to contaminants are mediated by diel temperature variability, seasonal hydrology, resource availability, and predator-prey relationships (Clark and Clements 2006; Buchwalter et al. 2007). From such data, researchers are developing bioenergetics models that predict contaminant effects on individual species in conjunction with non-contaminant stressors (Beyers et al. 1999a, b; Nisbet et al. 2000). For example, a bioenergetics model explained why 40- to 50-fold higher concentrations of metals were required to cause equivalent mortality in well-fed macroinvertebrates held at constant temperature in the laboratory compared to the same species in the field (Buchwalter et al. 2007). Moreover, energetics are key to predicting how ectotherms will respond to chronic contaminant exposure under changing water temperatures and flow regimes.
Fig. 4 Deviation from annual mean for $(a)$ average maximum and $(b)$ average minimum water temperatures. Daily water temperatures were collected at $15-$ min intervals at Stockton, Antioch, and Rio Vista, California between 1984 and 2007. (Data from www.iep.water.ca.gov)
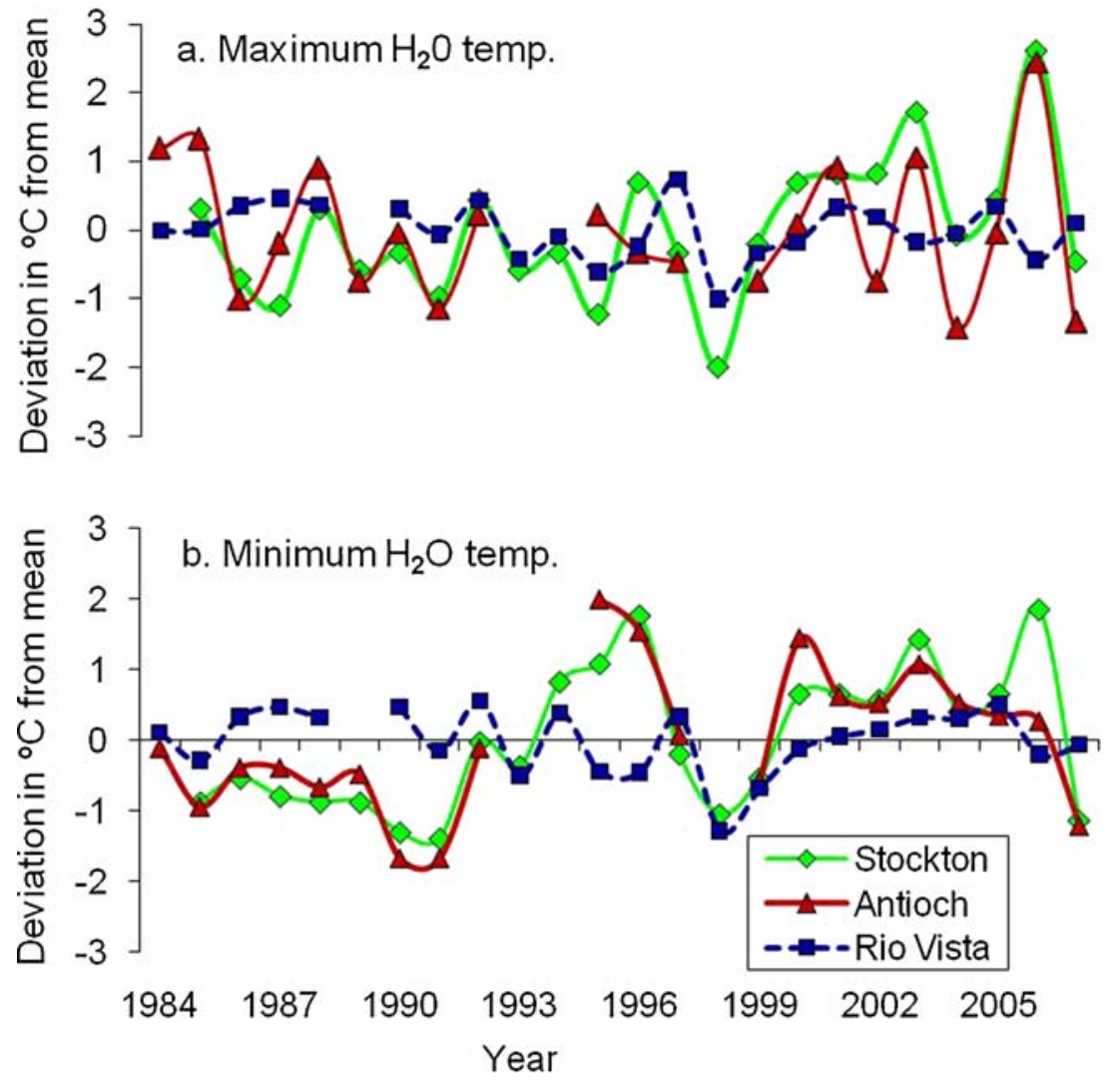
Progress has been made toward developing models of multiple stressors that predict change over time. Thomson et al. (2010) used Bayesian change-point analyses to examine the potential effect of abiotic and biotic factors on the decline of the four fish species discussed in this paper. Covariates included many of the non-contaminants that we discuss herein (e.g., temperature increases, reduction or variation in food) but did not include contaminants; however, after about 2000 those covariates no longer explained considerable variation in abundances. Dynamic energy budget theory evaluates effects of multiple stressors on growth and development in single species (Fujiwara et al. 2005; Jager and Klok 2010), and recently has been applied to explore toxic effects of Microcystis on a cladoceran under controlled laboratory conditions (Billoir et al. 2009). Dynamic energy budget theory has been used to assess causes of apoptosis (programmed cell death), endocrine disruption, and ovarian tumors in the longjaw mudsucker (Gillichthys mirabilis) in salt marshes on the Pacific coast of the USA (Anderson et al. 2006). These approaches hold promise for quantifying effects of individual stressors at one point in time, but a shortcoming of dynamic energy budget theory is that it cannot perform life cycle assessments (Nisbet et al. 2010). Life cycle analyses evaluate susceptibility versus resilience during changes in habitat and feeding at different life stages, but the data needed for building such models for multiple, interacting species subjected to multiple stressors are limited. Significant benefits could result from consistent, long-term monitoring of water temperature, geochemistry, and contaminants, and fish abundances, age/size ratios, and age classes (as potential proxies for energetic costs and reproductive success). When laboratory experiments are paired with acute and sublethal responses to contaminant mixtures in field exposures, we contend that energetics approaches will make it possible to discriminate sublethal effects of contaminants from those of other stressors causing declines of pelagic fishes in systems such as San Francisco Estuary. Field exposures within cages or diversion structures can provide opportunities to evaluate growth and biomarkers under environmentally realistic conditions (Hall et al. 1993; Oikari 2006; Ings et al. 2011). As such data become available, mensurative comparisons of field data in different locations (i.e., varied conditions) with models of energy budgets will clarify the net effects of multiple sublethal factors on fish abundances.

\section{Conclusions}

Researchers from around the world, including Europe (Matthiessen and Law 2002; Daufresne et al. 2007), South Africa (Bollmohr et al. 2007), and Asia (Luo et al. 2004), are struggling to quantify relationships between altered water quality, non-contaminant stressors, and declines of aquatic organisms. Although the San Francisco Estuary is one of the best studied estuaries in the world, the ecological effects of contaminants remain unquantified, and are difficult to investigate with standard methods based on acute toxicity. Our review of available evidence suggests that although sublethal contaminant effects are not the sole cause of past and ongoing fish declines, chronic bioenergetic costs resulting from exposure to metals, nitrogen-rich effluents, cyanobacterial blooms, and pesticides are likely contributors.

We have shown that accounting for seasonal and geographic patterns of life histories can clarify mechanisms important to particular life stages among species with habitats that range from anadromous to brackish to freshwater (Fig. 3). The greatest threat to pelagic species most likely occurs during larval life stages in the freshwater reaches of the Delta in late winter and spring. During this period, storms may greatly increase concentrations of toxicants when the physiologic ability of larvae to cope is undeveloped, when food limitation can result from acute toxicity of runoff to zooplankton prey, when competition from invasive species for food occurs, and when mixtures of contaminants are directly toxic or may simply have sublethal, inhibitory effects.

In general, sublethal, chronic exposure to contaminants may reduce reproduction, suppress immune function, increase expression of stress biomarkers (Fleeger et al. 2003), and damage olfactory capability (Sandahl et al. 2007). Sublethal contaminant exposure can impair immune function and swimming ability of delta smelt (Connon et al. 2011) and alter stress response and reproductive success in striped bass (Geist et al. 2007; Ostrach et al. 2008). We conclude that predicting the response of different fish species to contaminants requires considering the sensitivity and exposure of different life stages, the energy deficits due to multiple stressors, and the joint effects of temperature on metabolic rate and contaminant elimination.

Acknowledgments We thank James Orlando, Kelly Smalling, and several anonymous reviewers for helpful comments. This work was supported by cooperative agreement number 113325G004 between the University of California-Santa Barbara and the US Fish and Wildlife Service, and conducted as part of a working group convened in part at the National Center for Ecological Analysis and Synthesis.

\section{References}

Anderson, S.L., G.N. Cherr, S.G. Morgan, C.A. Vines, R.M. Higashi, W.A. Bennett, W.L. Rose, A.J. Brooks, and R.M. Nisbet. 2006. Integrating contaminant responses in indicator saltmarsh species. Marine Environmental Research 62: S317-S321.

Ankley, G.T., D.C. Bencic, M.S. Breen, T.W. Collette, R.B. Conolly, N. D. Denslow, S.W. Edwards, D.R. Ekman, N. Garcia-Reyero, K.M. 
Jensen, J.M. Lazorchak, D. Martinovic, D.H. Miller, E.J. Perkins, E. F. Orlando, D.L. Villeneuve, R.L. Wang, and K.H. Watanabe. 2009. Endocrine disrupting chemicals in fish: Developing exposure indicators and predictive models of effects based on mechanism of action. Aquatic Toxicology 92(3): 168-178.

Bailey, H.C., C. Alexander, C. Digiorgio, M. Miller, S.I. Doroshov, and D.E. Hinton. 1994. The effect of agricultural discharge on striped bass (Morone saxatalis) in California Sacramento-SanJoaquin drainage. Ecotoxicology 3(2): 123-142.

Baker, M.E., B. Ruggeri, L.J. Sprague, C. Eckhardt-Ludka, J. Lapira, I. Wick, L. Soverchia, M. Ubaldi, A.M. Polzonetti-Magni, D. Vidal-Dorsch, S. Bay, J.R. Gully, J.A. Reyes, K.M. Kelley, D. Schlenk, E.C. Breen, R. Sasik, and G. Hardiman. 2009. Analysis of endocrine disruption in Southern California coastal fish using an aquatic multispecies microarray. Environmental Health Perspectives 117(2): 223-230.

Beighley, R.E., T. Dunne, and J.M. Melack. 2008. Impacts of climate variability and land use alterations on frequency distributions of terrestrial runoff loading to coastal waters in southern California. Journal of the American Water Resources Association 44(1): 62-74.

Bennett, W. A. 2005. Critical assessment of the delta smelt population in the San Francisco estuary, California. Available at: http:// repositories.cdlib.org/jmie/sfews/vol3/iss2/art1. San Francisco Estuary and Watershed Science 3: 1.

Bennett, W.A., D.J. Ostrach, and D.E. Hinton. 1995. Larval striped bass condition in a drought-stricken estuary-Evaluating pelagic food-web limitation. Ecological Applications 5(3): 680-692.

Beyers, D.W., J.A. Rice, and W.H. Clements. 1999a. Evaluating biological significance of chemical exposure to fish using a bioenergetics-based stressor-response model. Canadian Journal of Fisheries and Aquatic Sciences 56(5): 823-829.

Beyers, D.W., J.A. Rice, W.H. Clements, and C.J. Henry. 1999b. Estimating physiological cost of chemical exposure: Integrating energetics and stress to quantify toxic effects in fish. Canadian Journal of Fisheries and Aquatic Sciences 56(5): 814-822.

Billoir, E., A.D. Ferrao, M.L. Delignette-Muller, and S. Charles. 2009. DEBtox theory and matrix population models as helpful tools in understanding the interaction between toxic cyanobacteria and zooplankton. Journal of Theoretical Biology 258(3): $380-388$.

Boening, D.W. 2000. Ecological effects, transport, and fate of mercury: A general review. Chemosphere 40(12): 1335-1351.

Bollmohr, S., J.A. Day, and R. Schulz. 2007. Temporal variability in particle-associated pesticide exposure in a temporarily open estuary, Western Cape, South Africa. Chemosphere 68(3): 479488.

Brady, J.A., W.W. Wallender, I. Werner, B.M. Fard, F.G. Zalom, M.N. Oliver, B.W. Wilson, M.M. Mata, J.D. Henderson, L.A. Deanovic, and S. Upadhaya. 2006. Pesticide runoff from orchard floors in Davis, California, USA: A comparative analysis of diazinon and esfenvalerate. Agriculture, Ecosystems \& Environment 115(1-4): 56-68.

Brar, N.K., C. Waggoner, J.A. Reyes, R. Fairey, and K.M. Kelley. 2010. Evidence for thyroid endocrine disruption in wild fish in San Francisco Bay, California, USA. Relationships to contaminant exposures. Aquatic Toxicology 96(3): 203-215.

Brooks, M.L., J.S. Meyer, and C.J. Boese. 2007a. Toxicity of copper to larval Pimephales promelas in the presence of photodegraded natural dissolved organic matter. Canadian Journal of Fisheries and Aquatic Sciences 64: 391-401.

Brooks, M.L., D.M. McKnight, and W.H. Clements. 2007b. Photochemical control of copper complexation by dissolved organic matter in Rocky Mountain Streams, Colorado USA. Limnology and Oceanography 52: 766-779.

Buchwalter, D.B., D.J. Cain, W.H. Clements, and S.N. Luoma. 2007. Using biodynamic models to reconcile differences between laboratory toxicity tests and field biomonitoring with aquatic insects. Environmental Science \& Technology 41(13): 48214828 .

Buck, K.N., J.R.M. Ross, A.R. Flegal, and K.W. Bruland. 2007. A review of total dissolved copper and its chemical speciation in San Francisco Bay, California. Environmental Research 105(1): 5-19.

Caissie, D. 2006. The thermal regime of rivers: A review. Freshwater Biology 51(8): 1389-1406.

Cayan, D., A. L. Luers, M. Hanemann, G. Franco, and B. Croes. 2006. Scenarios of climate change in California: An overview. Sacramento: California Climate Change Center. Available at: http://www.climatechange.ca.gov/biennial reports/ 2006report/index.html.

CDPR. 2009. 1990 to 2007, California Department of Pesticide Regulation, Annual pesticide use reports by county. In http:// www.cdpr.ca.gov/docs/pur/purmain.htm. Sacramento, CA Mary Votaw (ed), State of California

Chapman, P.M., W.J. Adams, M.L. Brooks, C.G. Delos, S.N. Luoma, W.A. Maher, H.M. Ohlendorf, T.S. Presser, and D.P. Shaw (eds.). 2010. Ecological assessment of selenium in the aquatic environment. Pensacola: SETAC Press.

Chaudry, M.A., and J.J.G. Zwolsman. 2008. Seasonal dynamics of dissolved trace metals in the Scheldt estuary: Relationship with redox conditions and phytoplankton activity. Estuaries and Coasts 31(2): 430-443.

Clark, J.L., and W.H. Clements. 2006. The use of in situ and stream microcosm experiments to assess population- and communitylevel responses to metals. Environmental Toxicology and Chemistry 25(9): 2306-2312.

Connon, R.E., J. Geist, J. Pfeiff, A.V. Loguinov, L.S. D'Abronzo, H. Wintz, C.D. Vulpe, and I. Werner. 2009. Linking mechanistic and behavioral responses to sublethal esfenvalerate exposure in the endangered delta smelt; Hypomesus transpacificus (Fam. Osmeridae). BMC Genomics 10: 18.

Connon, R.E., S. Beggel, L.S. D’Abronzo, J.P. Geist, J. Pfeiff, A.V. Loguinov, C.D. Vulpe, and I. Werner. 2011. Linking molecular biomarkers with higher level condition indicators to identify effects of copper exposures on the endangered delta smelt (Hypomesus transpacificus). Environmental Toxicology and Chemistry 30(2): 290-300.

Couillard, C.M., S.C. Courtenay, and R.W. Macdonald. 2008. Chemical-environment interactions affecting the risk of impacts on aquatic organisms: A review with a Canadian perspectiveInteractions affecting vulnerability. Environmental Reviews 16: $19-44$.

Daufresne, M., P. Bady, and J.F. Fruget. 2007. Impacts of global changes and extreme hydroclimatic events on macroinvertebrate community structures in the French Rhone River. Oecologia 151 (3): 544-559.

Debruyn, A.M.H., M.G. Ikonomou, and F. Gobas. 2004. Magnification and toxicity of PCBs, PCDDs, and PCDFs in upriver-migrating Pacific salmon. Environmental Science \& Technology 38(23): 6217-6224.

Dege, M., and L.R. Brown. 2004. Effect of outflow on spring and summertime distribution and abundance of larval and juvenile fishes in the upper San Francisco Estuary. In Early life history of fishes in the San Francisco Estuary and watershed, ed. L.R.B.F. Feyrer, R.L. Brown, and J.J. Orsi. Bethesda: American Fisheries Society.

Deng, D.F., F.C. Teh, and S.J. Teh. 2008. Effect of dietary methylmercury and seleno-methionine on Sacramento splittail larvae. Science of the Total Environment 407(1): 197-203.

Deng, D.-F., K. Zheng, F.-C. Teh, P.W. Lehman, and S.J. Teh. 2010. Toxic threshold of dietary microcystin (-LR) for quart Medaka. Toxicon 55: 787-794. 
Dietz, R., F. Riget, and E.W. Born. 2000. An assessment of selenium to mercury in Greenland marine animals. Science of the Total Environment 245: 15-24.

Dileanis, B. P., K. B. Bennett, and J. L. Domagalski. 2002. Occurrence and transport of diazinon in the Sacramento River, California and selected tributaries during three winter storms, January-February 2000. Available at: http://water.usgs.gov/pubs/ wri/wri02-4101. U.S. Geological Survey Water Resources Investigations Report 02-4101.

Dill, W.A., and A.J. Cordone. 1997. History and status of introduced fishes in California, 1871-1996: Conclusions. Fisheries 22(10): 15-18.

Doblin, M.A., S.B. Baines, L.S. Cutter, and G.A. Cutter. 2006. Sources and biogeochemical cycling of particulate selenium in the San Francisco Bay estuary. Estuarine, Coastal and Shelf Science 67: 681-694.

Domagalski, J.L., C.N. Alpers, D.G. Slotton, T.H. Suchanek, and S.M. Ayers. 2004. Mercury and methylmercury concentrations and loads in the Cache Creek watershed, California. Science of the Total Environment 327(1-3): 215-237.

Domenici, P., G. Claireaux, and D.J. McKenzie. 2007. Environmental constraints upon locomotion and predator-prey interactions in aquatic organisms: An introduction. Philosophical Transactions of the Royal Society B-Biological Sciences 362(1487): 19291936.

Ducrot, V., A.R.R. Pery, and L. Lagadic. 2010. Modelling effects of diquat under realistic exposure patterns in genetically differentiated populations of the gastropod Lymnaea stagnalis. Philosophical Transactions of the Royal Society B-Biological Sciences 365 (1557): 3485-3494.

Ducrotoy, J.P., M. Elliott, and V.N. De Jonge. 2000. The North Sea. Marine Pollution Bulletin 41(1-6): 5-23.

Dugdale, R.C., F.P. Wilkerson, V.E. Hogue, and A. Marchi. 2007. The role of ammonium and nitrate in spring bloom development in San Francisco Bay. Estuarine, Coastal and Shelf Science 73(12): $17-29$.

Dupont-Prinet, A., G. Claireaux, and D.J. McKenzie. 2009. Effects of feeding and hypoxia on cardiac performance and gastrointestinal blood flow during critical speed swimming in the sea bass Dicentrarchus labrax. Comparative Biochemistry and Physiology a-Molecular \& Integrative Physiology 154(2): 233-240.

Eder, K.J., H.R. Kohler, and I. Werner. 2007. Pesticide and pathogen: Heat shock protein expression and acetylcholinesterase inhibition in juvenile Chinook salmon in response to multiple stressors. Environmental Toxicology and Chemistry 26(6): 1233-1242.

Feyrer, F., M.L. Nobriga, and T.R. Sommer. 2007. Multidecadal trends for three declining fish species: Habitat patterns and mechanisms in the San Francisco Estuary, California, USA. Canadian Journal of Fisheries and Aquatic Sciences 64(4): 723-734.

Feyrer, F., K. Newman, M. Nobriga, and T. Sommer. 2010. Modeling the effects of future outflow on the abiotic habitat of an imperiled estuarine fish. Estuaries and Coasts published online, Sept

Fleeger, J.W., K.R. Carman, and R.M. Nisbet. 2003. Indirect effects of contaminants in aquatic ecosystems. Science of the Total Environment 317(1-3): 207-233.

Flegal, A.R., C.H. Conaway, G.M. Scelfo, S.A. Hibdon, and S.A. Sanudo-Wilhelmy. 2005. A review of factors influencing measurements of decadal variations in metal contamination in San Francisco Bay, California. Ecotoxicology 14(6): 645-660.

Floyd, E.Y., J.P. Geist, and I. Werner. 2008. Acute, sublethal exposure to a pyrethroid insecticide alters behavior, growth, and predation risk in larvae of the fathead minnow (Pimephales promelas). Environmental Toxicology and Chemistry 27(8): 1780-1787.

Fujiwara, M., B.E. Kendall, R.M. Nisbet, and W.A. Bennett. 2005. Analysis of size trajectory data using an energetic-based growth model. Ecology 86(6): 1441-1451.
Geist, J., I. Werner, K.J. Eder, and C.M. Leutenegger. 2007. Comparisons of tissue-specific transcription of stress response genes with whole animal endpoints of adverse effect in striped bass (Morone saxatilis) following treatment with copper and esfenvalerate. Aquatic Toxicology 85(1): 28-39.

Gensemer, R.W., and R.C. Playle. 1999. The bioavailability and toxicity of aluminum in aquatic environments. Critical Reviews in Environmental Science and Technology 29(4): 315-450.

Ger, K.A., S.J. Teh, and C.R. Goldman. 2009. Microcystin-LR toxicity on dominant copepods Eurytemora affinis and Pseudodiaptomus forbesi of the upper San Francisco Estuary. Science of the Total Environment 407(17): 4852-4857.

Goto, D., and W.G. Wallace. 2010. Bioenergetic responses of a benthic forage fish (Fundulus heteroclitus) to habitat degradation and altered prey community in polluted salt marshes. Canadian Journal of Fisheries and Aquatic Sciences 67(10): 1566-1584.

Gowdy, M. J. and L. F. Grober. 2003. Total Maximum Daily Load for Low Dissolved Oxygen in the San Joaquin River. Sacramento, CA.: Regional Water Quality Control Board Central Valley Region. Available at: http://www.waterboards. ca.gov/centralvalley/water_issues/tmdl/central valley projects/ san_joaquin_oxygen/low_do_report_6-2003/do_tmdl_rpt.pdf.

Greenfield, B.K., J.A. Davis, R. Fairey, C. Roberts, D. Crane, and G. Ichikawa. 2005. Seasonal, interannual, and long-term variation in sport fish contamination, San Francisco Bay. Science of the Total Environment 336: 25-43.

Greenfield, B.K., S.J. Teh, J.R.M. Ross, J. Hunt, G.H. Zhang, J.A. Davis, G. Ichikawa, D. Crane, S.S.O. Hung, D.F. Deng, F.C. Teh, and P.G. Green. 2008. Contaminant concentrations and histopathological effects in Sacramento splittail (Pogonichthys macrolepidotus). Archives of Environmental Contamination and Toxicology 55(2): 270-281.

Guinand, B., E.D.H. Durieux, C. Dupuy, F. Cerqueira, and M.L. Begout. 2010. Phenotypic and genetic differentiation in youngof-the-year common sole (Solea solea) at differentially contaminated nursery grounds. Marine Environmental Research 71(3): 195-206.

Guo, L., K. Kelley, and K.S. Goh. 2007. Evaluation of sources and loading of pesticides to the Sacramento River, California, USA, during a storm event of winter. Environmental Toxicology and Chemistry 26(11): 2274-2281.

Hall, L.W., M.C. Ziegenfuss, S.A. Fischer, J.A. Sullivan, and D.M. Palmer. 1993. The influence of contaminant and water-quality conditions on larval striped bass in the Potomac River and Upper Chesapeake Bay in 1990-An in situ study. Archives of Environmental Contamination and Toxicology 24(1): 1-10.

Harwood, A.D., J. You, and M.J. Lydy. 2009. Temperature as a toxicity identification evaluation tool for pyrethroid insecticides: Toxicokinetic confirmation. Environmental Toxicology and Chemistry 28(5): 1051-1058.

Herbrandson, C., S. Bradbury, and D. Swackhamer. 2003. Influence of suspended solids on acute toxicity of carbofuran to Daphnia magna. I. An evaluation of potential interactive mechanisms. Aquatic Toxicology 63: 343-355.

Heugens, E.H.W., A.J. Hendriks, T. Dekker, N.M. van Straalen, and W. Admiraal. 2001. A review of the effects of multiple stressors on aquatic organisms and analysis of uncertainty factors for use in risk assessment. Critical Reviews in Toxicology 31(3): 247-284.

Hoenicke, R., D.R. Oros, J.J. Oram, and K.M. Taberski. 2007. Adapting an ambient monitoring program to the challenge of managing emerging pollutants in the San Francisco Estuary. Environmental Research 105(1): 132-144.

Ibelings, B.W., and I. Chorus. 2007. Accumulation of cyanobacterial toxins in freshwater "seafood" and its consequences for public health: A review. Environmental Pollution 150(1): 177192. 
Ibelings, B. W. and K. E. Havens. 2008. Cyanobacterial toxins: a qualitative meta-analysis of concentrations, dosage and effects in freshwater, estuarine and marine biota. In Cyanobacterial Harmful Algal Blooms: State of the Science and Research Needs, edited by H. K. Hudnell

Ings, J.S., M.R. Servos, and M.M. Vijayan. 2011. Exposure to municipal wastewater effluent impacts stress performance in rainbow trout. Aquatic Toxicology 103(1-2): 85-91.

Ireland, D.S., G.A. Burton, and G.G. Hess. 1996. In situ toxicity evaluations of turbidity and photoinduction of polycyclic aromatic hydrocarbons. Environmental Toxicology and Chemistry 15(4): 574-581.

Jager, T., and C. Klok. 2010. Extrapolating toxic effects on individuals to the population level: The role of dynamic energy budgets. Philosophical Transactions of the Royal Society B: Biological Sciences 365(1557): 3531-3540.

Jassby, A. 2008. Phytoplankton in the Upper San Francisco Estuary: Recent biomass trends, their causes and their trophic significance. San Francisco Estuary and Watershed Science 6(1): 1-24.

Johnson, M. L., I. Werner, S. Teh, and F. Loge. 2010. Evaluation of chemical, toxicological, and histopathologic data to determine their role in the Pelagic Organism Decline Rancho Cordova, CA: Report to the Central Valley Regional Water Quality Control Board. Available at: http://www.waterboards.ca.gov/centralvalley/water issues/delta_water_quality/comprehensive_monitoring_program/ contaminant synthesis report.pdf.

Kidd, K.A., P.J. Blanchfield, K.H. Mills, V.P. Palace, R.E. Evans, J.M. Lazorchak, and R.W. Flick. 2007. Collapse of a fish population after exposure to a synthetic estrogen. Proceedings of the National Academy of Sciences of the United States of America 104(21): 8897-8901.

Kim, K.R., G. Owens, S.I. Kwon, K.H. So, D.B. Lee, and Y.S. Ok. 2011. Occurrence and environmental fate of veterinary antibiotics in the terrestrial environment. Water, Air, and Soil Pollution 214 (1-4): 163-174.

Koeman, J.H., W.H.M. Peeters, D.H.M. Koudstaal-Hol, P.S. Tjioe, and J.J.M. deGoeij. 1973. Mercury-selenium correlations in marine mammals. Nature 245: 385-386.

Kratzer, C. R., C. Zamora, and D. L. Knifong. 2002. Diazinon and chlorpyrifos loads in the San Joaquin River Basin, California, January and February 2000. U.S. Geological Survey Water Resources Investigations Report 02-4103. Available at: http:// pubs.usgs.gov/wri/wri034091/wrir034091.pdf.

Kroglund, F., B. Finstad, S.O. Stefansson, T.O. Nilsen, T. Kristensen, B.O. Rosseland, H.C. Teien, and B. Salbu. 2007. Exposure to moderate acid water and aluminum reduces Atlantic salmon postsmolt survival. Aquaculture 273(2-3): 360-373.

Kuivila, K.M., and M. Hladik. 2008. Understanding the occurrence and transport of current-use pesticide in the San Francisco Estuary Watershed. San Francisco Estuary and Watershed Science 6(Article 2): 1-19.

Landis, W.G., P.B. Duncan, E.H. Hayes, A.J. Markiewicz, and J.F. Thomas. 2004. A regional retrospective assessment of the potential stressors causing the decline of the Cherry Point Pacific herring run. Human and Ecological Risk Assessment 10(2): 271-297.

Lavado, R., J.M. Rimoldi, and D. Schlenk. 2009a. Mechanisms of fenthion activation in rainbow trout (Oncorhynchus mykiss) acclimated to hypersaline environments. Toxicology and Applied Pharmacology 235(2): 143-152.

Lavado, R., J.E. Loyo-Rosales, E. Floyd, E.P. Kolodziej, S. Snyder, D. L. Sedlak, and D. Schlenk. 2009b. Site-specific profiles of estrogenic activity in agricultural areas of California's inland waters. Environmental Science \& Technology 43: 9110-9116.

Lehman, P.W. 2000. Phytoplankon biomass, cell diameter, and species composition in the low salinity zone of northern San Francisco Bay estuary. Estuaries 23(2): 216-230.
Lehman, P.W. 2004. The influence of climate on mechanistic pathways that affect lower food web production in northern San Francisco Bay estuary. Estuaries 27(2): 311-324.

Lehman, P.W., J. Sevier, J. Giulianotti, and M. Johnson. 2004. Sources of oxygen demand in the lower San Joaquin River, California. Estuaries 27: 405-418.

Lehman, P. W., G. Boyer, C. Hall, S. Waller, and K. Gehrts. 2005. Distribution and toxicity of a new colonial Microcystis aeruginosa bloom in the San Francisco Bay Estuary, California. Hydrobiologia 541: 87-99.

Lehman, P.W., G. Boyer, M. Satchwell, and S. Waller. 2008. The influence of environmental conditions on the seasonal variation of Microcystis cell density and microcystins concentration in San Francisco Estuary. Hydrobiologia 600: 187-204.

Lehman, P.W., S.J. Teh, G.L. Boyer, M.L. Nobriga, E. Bass, and C. Hogle. 2010. Initial impacts of Microcystis aeruginosa blooms on the aquatic food web in the San Francisco Estuary. Hydrobiologia 637: 229-248.

Linton, T.K., I.J. Morgan, P.J. Walsh, and C.M. Wood. 1998a. Chronic exposure of rainbow trout (Oncorhynchus mykiss) to simulated climate warming and sublethal ammonia: A year-long study of their appetite, growth, and metabolism. Canadian Journal of Fisheries and Aquatic Sciences 55(3): 576-586.

Linton, T.K., I.J. Morgan, P.J. Walsh, and C.M. Wood. 1998b. Chronic exposure of rainbow trout (Oncorhynchus mykiss) to simulated climate warming and sublethal ammonia: a year-long study of their appetite, growth, and metabolism. Canadian Journal of Fisheries and Aquatic Sciences 55: 576-586.

Lopes de Souza, S.M.L., E.C. de Vasconcelos, M. Dziedzic, and C.M. R. de Oliveira. 2009. Environmental risk assessment of antibiotics: An intensive care unit analysis. Chemosphere 77(7): 962-967.

Loraine, G.A., and M.E. Pettigrove. 2006. Seasonal variations in concentrations of pharmaceuticals and personal care products in drinking water and reclaimed wastewater in Southern California. Environmental Science \& Technology 40(3): 687-695.

Luo, X.J., B.X. Mai, Q.S. Yang, J.M. Fu, G.Y. Sheng, and Z.S. Wang. 2004. Polycyclic aromatic hydrocarbons (PAHs) and organochlorine pesticides in water columns from the Pearl River and the Macao harbor in the Pearl River Delta in South China. Marine Pollution Bulletin 48(11-12): 1102-1115.

Luoma, S.N., and T.S. Presser. 2009. Emerging opportunities in management of selenium contamination. Environmental Science \& Technology 43(22): 8483-8487.

Lydy, M.J., T.W. Lohner, and S.W. Fisher. 1990. Influence of pH, temperature and sediment type on the toxicity, accumulation and degradation of parathion in aquatic systems. Aquatic Toxicology 17(1): 27-44.

Malbrouck, C., and P. Kestemont. 2006. Effects of microcystins on fish. Environmental Toxicology and Chemistry 25(1): 72-86.

Matthiessen, P., and R.J. Law. 2002. Contaminants and their effects on estuarine and coastal organisms in the United Kingdom in the late twentieth century. Environmental Pollution 120(3): 739-757.

Meyer, J.N., and R.T. Di Giuliuo. 2003. Heritable adaptation and fitness costs in killifish (Fundulus beteroclitus) inhabiting a polluted estuary. Ecological Applications 13(2): 490-503.

Meyer, J.N., J.D. Smith, G.W. Winston, and R.T. Di Giulio. 2003. Antioxidant defenses in killifish (Fundulus heteroclitus) exposed to contaminated sediments and model prooxidants: Short-term and heritable responses. Aquatic Toxicology 65(4): 377-395.

Morgan, I.J., D.G. McDonald, and C.M. Wood. 2001. The cost of living for freshwater fish in a warmer, more polluted world. Global Change Biology 7(4): 345-355.

Moyle, P.B. 2002. Inland fishes of California. Revised and expanded. Berkeley: University of California. 
Moyle, P.B., B. Herbold, D.E. Stevens, and L.W. Miller. 1992. Lifehistory and status of Delta Smelt in the Sacramento-San-Joaquin Estuary, California. Transactions of the American Fisheries Society 121(1): 67-77.

Munkes, B. 2005. Eutrophication, phase shift, the delay and the potential return in the Greifswalder Bodden, Baltic Sea. Aquatic Sciences 67(3): 372-381.

Ng, T.Y.T., J.S. Klinck, and C.M. Wood. 2009. Does dietary Ca protect against toxicity of a low dietborne $\mathrm{Cd}$ exposure to the rainbow trout? Aquatic Toxicology 91(1): 75-86.

Nichols, F.H., J.E. Cloern, S.N. Luoma, and D.H. Peterson. 1986. The modification of an estuary. Science 231(4738): 567-573.

Nilsen, T.O., L.O.E. Ebbesson, O.G. Kverneland, F. Kroglund, B. Finstad, and S.O. Stefansson. 2010. Effects of acidic water and aluminum exposure on gill $\mathrm{Na}+, \mathrm{K}+-$ ATPase alpha-subunit isoforms, enzyme activity, physiology and return rates in Atlantic salmon (Salmo salar L.). Aquatic Toxicology 97(3): $250-259$.

Nisbet, R., E. Muller, K. Lika, and S. Kooijman. 2000. From molecules to ecosystems through dynamic energy budget models. Journal of Animal Ecology 69: 913-926.

Nisbet, R.M., E. McCauley, and L.R. Johnson. 2010. Dynamic energy budget theory and population ecology: Lessons from Daphnia. Philosophical Transactions of the Royal Society B: Biological Sciences 365(1557): 3541-3552.

Nobriga, M.L., and F. Feyrer. 2008. Diet composition in San Francisco Estuary striped bass: Does trophic adaptability have its limits? Environmental Biology of Fishes 83(4): 509-517.

Oikari, A. 2006. Caging techniques for field exposures of fish to chemical contaminants. Aquatic Toxicology 78(4): 370-381.

Ostrach, D.J., J.M. Low-Marchelli, K.J. Eder, S.J. Whiteman, and J.G. Zinkl. 2008. Maternal transfer of xenobiotics and effects on larval striped bass in the San Francisco Estuary. Proceedings of the National Academy of Sciences of the United States of America 105(49): 19354-19359.

Pistole, D.H., J.D. Peles, and K. Taylor. 2008. Influence of metal concentrations, percent salinity, and length of exposure on the metabolic rate of fathead minnows (Pimephales promelas). Comparative Biochemistry and Physiology C-Toxicology \& Pharmacology 148(1): 48-52.

Porter, W.P., R. Hinsdill, A. Fairbrother, L.J. Olson, J. Jaeger, T. Yuill, S. Bisgaard, W.G. Hunter, and K. Nolan. 1984. Toxicant-diseaseenvironment interactions associated with suppression of immune system, growth, and reproduction. Science 224: 1014-1017.

Portner, H.O., and R. Knust. 2007. Climate change affects marine fishes through the oxygen limitation of thermal tolerance. Science 315(5808): 95-97.

Relyea, R., and J. Hoverman. 2006. Assessing the ecology in ecotoxicology: A review and synthesis in freshwater systems. Ecology Letters 9(10): 1157-1171.

Robinson, A.A., J.B. Belden, and M.J. Lydy. 2005. Toxicity of fluoroquinolone antibiotics to aquatic organisms. Environmental Toxicology and Chemistry 24(2): 423-430.

Rohr, J.R., J.L. Kerby, and A. Sih. 2006. Community ecology as a framework for predicting contaminant effects. Trends in Ecology \& Evolution 21: 606-613.

Rosenfield, J.A., and R.D. Baxter. 2007. Population dynamics and distribution patterns of longfin smelt in the San Francisco estuary. Transactions of the American Fisheries Society 136(6): $1577-1592$.

Roy, R.L., and P.G.C. Campbell. 1997. Decreased toxicity of Al to juvenile Atlantic salmon (Salmo salar) in acidic soft water containing natural organic matter: A test of the free-ion model. Environmental Toxicology and Chemistry 16(9): 1962-1969.

Saiki, M.K., M.R. Jennings, and T.W. May. 1992. Selenium and other elements in fresh-water fishes from the irrigated San Joaquin
Valley, California. Science of the Total Environment 126(1-2): 109-137.

Sandahl, J.F., D.H. Baldwin, J.J. Jenkins, and N.L. Scholz. 2007. A sensory system at the interface between urban stormwater runoff and salmon survival. Environmental Science \& Technology 41 (8): 2998-3004.

Schindler, D.W. 1977. Evolution of phosphorus limitation in lakes. Science 195: 260-262.

SFEI. 2007. The pulse of the estuary: Monitoring and managing water quality in the San Francisco Estuary. Oakland: San Francisco Estuary Institute.

Sommer, T., C. Armor, R. Baxter, R. Breuer, L. Brown, M. Chotkowski, S. Culberson, F. Feyrer, M. Gingras, B. Herbold, W. Kimmerer, A. Mueller-Solger, M. Nobriga, and K. Souza. 2007. The collapse of pelagic fishes in the Upper San Francisco Estuary. Fisheries 32(6): 270-277.

Spearow, J.L., R.S. Kota, and D.J. Ostrach. 2011. Environmental contaminant effect on juvenile striped bass in the San Francisco Estuary, California, USA. Environmental Toxicology and Chemistry 30(2): 393-402.

Spurlock, F., and M. Lee. 2008. Synthetic pyrethroid use patterns, properties, and environmental effects. In Synthetic pyrethroids: Occurrence and behavior in aquatic environments, ed. J. Gan et al. Washington: American Chemical Society.

Stewart, A.R., S.N. Luoma, C.E. Schlekat, M.A. Doblin, and K.A. Hieb. 2004. Food web pathway determines how selenium affects aquatic ecosystems: A San Francisco Bay case study. Environmental Science \& Technology 38(17): 4519-4526.

Suikkanen, S., G.O. Fistarol, and E. Graneli. 2005. Effects of cyanobacterial allelochemicals on a natural plankton community. Marine Ecology Progress Series 287: 1-9.

Thomson, J., W. Kimmerer, L. Brown, K. Newman, R.M. Nally, W. Bennett, F. Feyrer, and E. Fleishman. 2010. Bayesian changepoint analysis of abundance trends for pelagic fishes in the upper San Francisco Estuary. Ecological Applications 20(4): 14311448.

Tillmanns, A.R., A.E. Wilson, F.R. Pick, and O. Sarnelle. 2008. Metaanalysis of cyanobacterial effects on zooplankton population growth rate: Species-specific responses. Fundamental and Applied Limnology 171(4): 285-295.

USEPA. 2008. Fourth five-year review report for Iron Mountain Mine superfund site, Redding, California. Available from: http://yosemite.epa. gov/r9/sfund/r9sfdocw.nsf/3dc283e6c5d6056f88257426007417a2/ 0debbf5424a57c908825774900824131! OpenDocument, edited by K. Salyer. San Francisco, California 94105: U.S. Environmental Protection Agency.

USGS, C. W. S. C. 2011. Hydrologic data: California Water Science Center http://ca.water.usgs.gov/.

Wagner, R.W., M. Stacey, L.R. Brown, and M. Dettinger. 2011. Statistical models of temperature in the Sacramento-San Joaquin Delta under climate-change scenarios and ecological implications. Estuaries and Coasts 34(3): 544-556.

Wallace, W.G., B.G. Lee, and S.N. Luoma. 2003. Subcellular compartmentalization of $\mathrm{Cd}$ and $\mathrm{Zn}$ in two bivalves. I. Significance of metal-sensitive fractions (MSF) and biologically detoxified metal (BDM). Marine Ecology Progress Series 249: 183-197.

Werner, I., and K. Moran. 2008. Effects of pyrethroid insecticides on aquatic organisms. In Synthetic pyrethroids: Occurrence and behavior in aquatic environments, ed. J. Gan et al. Washington: American Chemical Society.

Werner, I., L.A. Deanovic, V. Connor, V. de Vlaming, H.C. Bailey, and D.E. Hinton. 2000. Insecticide-caused toxicity to Ceriodaphnia dubia (Cladocera) in the Sacramento-San Joaquin River Delta, California, USA. Environmental Toxicology and Chemistry 19(1): 215-227. 
Werner, I., L. Deanovic, C. Reece, D. Markiewicz, M. Stillway, J. Khamphanh, R. E. Connon, and S. Beggel. 2009. Pelagic organism decline (POD): Acute and chronic invertebrate and fish toxicity testing in the Sacramento-San Joaquin Delta 2008-2010, progress report, February 27, 2009. Sacramento, CA: Interagency Ecological Program Available at: http:/www.waterboards.ca.gov/waterrights/ water_issues/programs/bay_delta/deltaflow/docs/exhibits/sac rcsd/ srcsd exh2b.pdf.

Werner, I., L.A. Deanovic, D. Markiewicz, M. Khamphanh, C.K. Reece, M. Stillway, and C. Reece. 2010. Monitoring acute and chronic water column toxicity in the Northern Sacramento-San Joaquin Estuary, California, USA, using the euryhaline amphipod, Hyalella azteca: 2006-2007. Environmental Toxicology and Chemistry 29(10): 2190-2199.

Weston, D.P., and M.J. Lydy. 2010. Urban and agricultural sources of pyrethroid insecticides to the Sacramento-San Joaquin Delta of California. Environmental Science \& Technology 44(5): 18331840.

Weston, D.P., J. You, A.D. Harwood, and M.J. Lydy. 2009. Whole sediment toxicity identification evaluation tools for pyrethroid insecticides: III. Temperature manipulation. Environmental Toxicology and Chemistry 28(1): 173-180.

Wilson, A.E., O. Sarnelle, and A.R. Tillmanns. 2006. Effects of cyanobacterial toxicity and morphology on the population growth of freshwater zooplankton: Meta-analyses of laboratory experiments. Limnology and Oceanography 51(4): 1915-1924.
Wirgin, I., and J.R. Waldman. 2004. Resistance to contaminants in North American fish populations. Mutation Research, Fundamental and Molecular Mechanisms of Mutagenesis 552 (1-2): 73-100.

Wirgin, I., N.K. Roy, M. Loftus, R.C. Chambers, D.G. Franks, and M. E. Hahn. 2011. Mechanistic basis of resistance to PCBs in Atlantic Tomcod from the Hudson River. Science 331(6022): $1322-1325$.

Xie, L.T., and P.L. Klerks. 2004. Fitness cost of resistance to cadmium in the least killifish (Heterandria formosa). Environmental Toxicology and Chemistry 23(6): 1499-1503.

Yang, D.Y., Y.W. Chen, J.M. Gunn, and N. Belzile. 2008. Selenium and mercury in organisms: Interactions and mechanisms. Environmental Reviews 16: 71-92.

Yang, D.Y., X. Ye, Y.W. Chen, and N. Belzile. 2010. Inverse relationships between selenium and mercury in tissues of young walleye (Stizosedion vitreum) from Canadian boreal lakes. Science of the Total Environment 408(7): 1676-1683.

Yang, D.Y., Y.W. Chen, and N. Belzile. 2011. Evidences of nonreactive mercury-selenium compounds generated from cultures of Pseudomonas fluorescens. Science of the Total Environment 409(9): 1697-1703.

Yuan, Z.P., S. Courtenay, R.C. Chambers, and I. Wirgin. 2006. Evidence of spatially extensive resistance to PCBs in an anadromous fish of the Hudson River. Environmental Health Perspectives 114(1): 77-84. 